\title{
HTAP_v2.2: a mosaic of regional and global emission grid maps for 2008 and 2010 to study hemispheric transport of air pollution
}

\author{
G. Janssens-Maenhout ${ }^{1,12}$, M. Crippa ${ }^{1}$, D. Guizzardi ${ }^{1}$, F. Dentener ${ }^{1}$, M. Muntean ${ }^{1}$, G. Pouliot ${ }^{2}$, T. Keating ${ }^{3}$, \\ Q. Zhang ${ }^{4}$, J. Kurokawa ${ }^{5}$, R. Wankmüller ${ }^{6}$, H. Denier van der Gon ${ }^{7}$, J. J. P. Kuenen ${ }^{7}$, Z. Klimont ${ }^{8}$, G. Frost ${ }^{9}$, \\ S. Darras ${ }^{10}$, B. Koffi ${ }^{1}$, and M. $\mathbf{L i}^{4,11}$ \\ ${ }^{1}$ European Commission, Joint Research Centre, Institute for Environment and Sustainability, Via Fermi, 2749, 21027 \\ Ispra (VA), Italy \\ ${ }^{2}$ US EPA - Office of Research and Development, Research Triangle Park, North Carolina 27711, USA \\ ${ }^{3}$ US EPA - Office of Air \& Radiation, 1200 Pennsylvania Av. NW, Washington DC 20460, USA \\ ${ }^{4}$ Ministry of Education Key Laboratory for Earth System Modelling, Center for Earth System Science, Tsinghua University, \\ Beijing, China \\ ${ }^{5}$ Asia Center for Air Pollution Research, 1182 Sowa, Nishi-ku, Niigata, Niigata, 950-2144, Japan \\ ${ }^{6}$ EMEP - Centre on Emission Inventory \& Projection (CEIP), Federal Environment Agency, Spittelauer Lände, 5, 1090 \\ Vienna, Austria \\ ${ }^{7}$ TNO, Department of Climate, Air and Sustainability, Princetonlaan 6, 3584 CB Utrecht, the Netherlands \\ ${ }^{8}$ International Institute for Applied Analysis, Schloßplatz, 1, 2361 Laxenburg, Austria \\ ${ }^{9}$ NOAA Earth System Research Laboratory \& University of Colorado/CIRES, Boulder, CO, USA \\ ${ }^{10}$ Observatoire Midi-Pyrénées, CNRS, SEDOO, Toulouse, France \\ ${ }^{11}$ State Key Joint Laboratory of Environment Simulation and Pollution Control, School of Environment, Tsinghua University, \\ Beijing, China \\ ${ }^{12}$ Ghent University, Campus Ardoyen, Ghent-Zwijnaarde, Belgium
}

Correspondence to: G. Janssens-Maenhout (greet.maenhout@jrc.ec.europa.eu)

Received: 19 March 2015 - Published in Atmos. Chem. Phys. Discuss.: 29 April 2015

Revised: 30 July 2015 - Accepted: 27 August 2015 - Published: 15 October 2015

\begin{abstract}
The mandate of the Task Force Hemispheric Transport of Air Pollution (TF HTAP) under the Convention on Long-Range Transboundary Air Pollution (CLRTAP) is to improve the scientific understanding of the intercontinental air pollution transport, to quantify impacts on human health, vegetation and climate, to identify emission mitigation options across the regions of the Northern Hemisphere, and to guide future policies on these aspects.

The harmonization and improvement of regional emission inventories is imperative to obtain consolidated estimates on the formation of global-scale air pollution. An emissions data set has been constructed using regional emission grid maps (annual and monthly) for $\mathrm{SO}_{2}, \mathrm{NO}_{x}, \mathrm{CO}, \mathrm{NMVOC}, \mathrm{NH}_{3}$, $\mathrm{PM}_{10}, \mathrm{PM}_{2.5}, \mathrm{BC}$ and $\mathrm{OC}$ for the years 2008 and 2010, with the purpose of providing consistent information to global and regional scale modelling efforts.
\end{abstract}

This compilation of different regional gridded inventories - including that of the Environmental Protection Agency (EPA) for USA, the EPA and Environment Canada (for Canada), the European Monitoring and Evaluation Programme (EMEP) and Netherlands Organisation for Applied Scientific Research (TNO) for Europe, and the Model Intercomparison Study for Asia (MICS-Asia III) for China, India and other Asian countries - was gap-filled with the emission grid maps of the Emissions Database for Global Atmospheric Research (EDGARv4.3) for the rest of the world (mainly South America, Africa, Russia and Oceania). Emissions from seven main categories of human activities (power, industry, residential, agriculture, ground transport, aviation and shipping) were estimated and spatially distributed on a common grid of $0.1^{\circ} \times 0.1^{\circ}$ longitude-latitude, to yield 
monthly, global, sector-specific grid maps for each substance and year.

The HTAP_v2.2 air pollutant grid maps are considered to combine latest available regional information within a complete global data set. The disaggregation by sectors, high spatial and temporal resolution and detailed information on the data sources and references used will provide the user the required transparency. Because HTAP_v2.2 contains primarily official and/or widely used regional emission grid maps, it can be recommended as a global baseline emission inventory, which is regionally accepted as a reference and from which different scenarios assessing emission reduction policies at a global scale could start.

An analysis of country-specific implied emission factors shows a large difference between industrialised countries and developing countries for acidifying gaseous air pollutant emissions $\left(\mathrm{SO}_{2}\right.$ and $\left.\mathrm{NO}_{x}\right)$ from the energy and industry sectors. This is not observed for the particulate matter emissions $\left(\mathrm{PM}_{10}, \mathrm{PM}_{2.5}\right)$, which show large differences between countries in the residential sector instead. The per capita emissions of all world countries, classified from low to high income, reveal an increase in level and in variation for gaseous acidifying pollutants, but not for aerosols. For aerosols, an opposite trend is apparent with higher per capita emissions of particulate matter for low income countries.

\section{Introduction}

Intercontinental transport of air pollution occurs on timescales of days to weeks and, depending on the specific type of pollutant, may contribute substantially to local scale pollution episodes (HTAP, 2010). Common international understanding of global air pollution and its influence on human health, vegetation and climate, is imperative for providing a basis for future international policies and is a prime objective for the Task Force Hemispheric Transport of Air Pollution (TF HTAP $)^{1}$. While nowadays many countries and regions report their air pollutant emissions, these estimates may not be readily accessible, or may be difficult to interpret without additional information, and their quality may differ widely, having various degrees of detail and being presented in different formats.

The UN Framework Convention on Climate Change (UNFCCC) requires official inventory reporting that complies with the TACCC principles of quality: transparency, accuracy, consistency, comparability and completeness ${ }^{2}$, reviewed by UNFCCC roster experts and made available at their website (UNFCCC, 2013). Under the CLRTAP (Convention on Long-range Transboundary Air Pollution) the parties need to report emissions to the EMEP (European Monitoring and Evaluation Programme) Centre on Emission In-

\footnotetext{
${ }^{1}$ More info on www.htap.org.

${ }^{2}$ Timeliness has recently also been considered.
}

ventories and Projections (CEIP), which also reviews data on completeness and consistency. Responsibility of providing emission inventories to several international bodies is often distributed within a particular country; e.g. the methane inventory of some Annex I countries is provided by different national institutions. Although they represent the same region, they might be different, which is often the case and leads to confusion (Janssens-Maenhout et al., 2012).

Currently available emission inventories differ in spatial and temporal resolution ("consistency"), in coverage of geographical area, time period and list of compounds ("completeness") and in the sector-specific details of the source calculation ("transparency"). Moreover the official inventories submitted by countries have at least a 1-year time lag, are updated with different frequency and with or without review of the historical time series. The work of Lamarque et al. (2010) provides a unique example of a comprehensive "composite" historical emissions data set spanning from 1850 to 2000 , using a similar methodology of combining country level inventories for most OECD (Organisation for Economic Cooperation and Development) countries with research inventories for Asia and EDGAR for other regions. The data set also provided harmonized base-year (2000) emissions that were used as a starting point for the development of the socalled RCPs (representative concentration pathways) emission scenarios (e.g. Moss et al., 2010; van Vuuren et al., 2011). For other years and specific model domains covering multiple regions, atmospheric modellers often compile their own emission inputs drawing upon different pieces of the available inventories. These compilations involve sometimes arbitrary choices, and are often not clearly described or evaluated. For example, the atmospheric modelling groups, which contributed to the HTAP multi-model experiments described in HTAP (2010), used their own best estimates for emissions for the year 2001, obtaining in some cases comparable global emissions (e.g. for $\mathrm{NO}_{x}$ and $\mathrm{SO}_{2}$ model input), and sometimes getting larger differences in the model input (e.g. for NMVOC emissions). Moreover, Streets et al. (2010) evaluated the consistency of the emissions used in the various models and nationally reported emissions. For a followup study in HTAP Phase 2, it was recommended to provide a harmonised emissions data set for the years 2008 and 2010 in line with the following four major objectives:

1. to facilitate development of mitigation policies by making use of well documented national inventories;

2. to identify missing (anthropogenic) sources and gap fill them with scientific inventories for a more complete picture at the global scale;

3. to provide a reference data set for further emission compilation activities (benchmarking or scenario exercises);

4. to provide a single entry point for consistent global and regional modelling activities focusing on the contribu- 
tion of long-range (intercontinental) air pollution to regional air quality issues.

A harmonized global, gridded, air pollution emission data set has been compiled with officially reported, gridded inventories at the national scale, to the extent possible and complemented with science-based inventories for regions and sectors where nationally reported data were not available.

For a preceding data $\mathrm{set}^{3}$ of EDGAR-HTAP_v1, the nationally reported emissions (combined with regional scientific inventories and gap-filled with the global set originating from EDGARv4.2) were all gridded with geospatial data from EDGAR (Janssens-Maenhout et al., 2012). However, this time we used regional gridded emissions, which are officially accepted and complemented with EDGARv4.3 grid maps (Janssens-Maenhout et al., 2013) for countries or sectors without reported data.

The resulting data set, named HTAP_v2.2, is a compilation of annual and monthly grid maps of anthropogenic air pollution emissions (with a $0.1^{\circ} \times 0.1^{\circ}$ grid resolution). It contains region-specific information on human activity (concerning intensity and geospatial distribution) and on fuel, technology- and process-dependent emission factors and end-of-pipe abatement, but it is not as consistent as a globally consistent emission inventory using international statistics and global geospatial distributions. With the perspective of being used in chemical transport models, this inventory includes the atmospheric gaseous pollutants $\left(\mathrm{SO}_{2}, \mathrm{NO}_{x}, \mathrm{CO}\right.$, $\mathrm{NMVOC}^{4}, \mathrm{NH}_{3}$ ) and particulate matter with carbonaceous speciation $\left(\mathrm{PM}_{10}, \mathrm{PM}_{2.5}, \mathrm{BC} \text { and } \mathrm{OC}\right)^{5}$.

${ }^{3}$ EDGAR-HTAP_v1 completed in October 2010 comprises sector-specific annual grid maps for the 6 years from 2000 to 2005 and covers air pollutants $\left(\mathrm{CH}_{4}, \mathrm{CO}, \mathrm{NH}_{3}, \mathrm{NMVOC}, \mathrm{SO}_{2}\right.$ and $\left.\mathrm{NO}_{x}\right)$ and particulate matter with its carbonaceous speciation $\left(\mathrm{PM}_{10}\right.$, $\mathrm{PM}_{2.5}$, BC and OC). The annual grid maps of $0.1^{\circ} \times 0.1^{\circ}$ resolution are made available via http://edgar.jrc.ec.europa.eu/national_ reported_data/htap.php and the CIERA and ECCAD servers. Documentation is available in the HTAP_v1 EUR25229EN report of Janssens-Maenhout et al. (2012) (http://edgar.jrc.ec.europa.eu/htap/ EDGAR-HTAP_v1_final_jan201acp-2015-214-g02.pdf).

${ }^{4}$ The non-methane volatile organic compounds (NMVOC) of HTAP_v2.2 are defined as the total sum of Alkanols, Ethane, Propane, Butanes, Pentanes, Hexanes and higher, Ethene, Propene, Ethyne, Isoprenes, Monoterpenes, Other alk(adi)enes/alkynes, Benzene, Methylbenzene, Dimethylbenzenes, Trimethylbenzenes, Other aromatics, Esters, Ethers, Chlorinated hydrocarbons, Methanal, Other alkanals, Alkanones, Acids, Other Aromatics, all expressed in their full weight, not just $\mathrm{C}$.

${ }^{5}$ Whereas $\mathrm{PM}_{10}$ is defined as primary emitted aerosols with aerodynamic diameter up to 10 micrometer, $\mathrm{PM}_{2.5}$ is a subset with aerodynamic diameter up to 2.5 micrometer, including elemental carbon $(\mathrm{BC})$, organic carbon $(\mathrm{OC}), \mathrm{SO} 4^{2-}, \mathrm{NO}^{1-}$, crustal material, metal and other dust particles. Note that $\mathrm{BC}$ and $\mathrm{OC}$ are additive to each other but not to $\mathrm{PM}_{2.5}\left(\{\mathrm{BC}, \mathrm{OC}\} \subset\left\{\mathrm{PM}_{2.5}\right\}\right.$ and $\left.\left\{=\mathrm{PM}_{2.5}\right\} \subset\left\{\mathrm{PM}_{10}\right\}\right)$.
This paper provides a detailed description of the data sets and of the methodology used to compute the $0.1^{\circ} \times 0.1^{\circ}$ grid maps for 2008 and 2010, which are delivered via the EDGAR JRC website (see Sect. 4). Section 2 defines the considered emitting sectors and presents the original data sources: (a) the officially accepted regional/national gridded emission inventories, which were mainly provided by national and international institutions, and (b) EDGAR_v4.3 for gap filling the remaining regions and/or sectors for some substances. In the HTAP_v2.2 database, grid maps were merged together with a "collage/mosaic" approach instead of gridding the global emission inventory with one single proxy data set, as done in for the EDGAR-HTAP_v1 data set compilation (JanssensMaenhout et al., 2012). The HTAP_v2.2 inventory aims to obtain more local accuracy on the location of single point sources compared to the previous HTAP_v1, but the downside is that a consistent single location of a specific source of multi-pollutants is no longer ensured, when data originated from different sources, possibly leading to spurious chemical reactions involving non-linear chemistry in the air quality models. Sect. 3 discusses the resulting grid maps and addresses the contents of the HTAP_v2.2 compilation methodology, the assumptions, dataflows and consistency of the data used to create the global grid maps. Whereas HTAP_v2.2 uses more regional bottom-up data (local information on emission factors, on assumed penetration of technology and end-of-pipe control measures in the facilities), the higher spatial accuracy is sometimes overshadowed by artefacts at borders - at least when graphically displaying the data. This is followed with an evaluation of the HTAP_v2.2 by comparing per capita emissions, emissions per unit of GDP (gross domestic product) and implied emission factors for the different countries. The concluding Sect. 4 summarises the purposes, content and access to this data set that is currently in use by the HTAP modellers community.

\section{Methods}

\subsection{Defining the sector-specific breakdown}

An overview of the data sources used is given in Table 1a. For the development of HTAP_v2.2, a detailed cross-walk table of the US EPA, EDGAR and EMEP (sub)sector-specific activities has been setup, using all human activities defined in detail by IPCC (1996) and applied for the reporting under the UNFCCC. The US EPA and the contributing data set from Environment Canada, provided the most detailed cross-walk matrix between the categories used in their national inventory and the full-fledged set of all IPCC categories. However, a higher level of aggregation was needed to find a common basis with the Asian emission inventories, which led to the establishment of the seven categories: aircraft, international shipping, power industry, industry, ground transport, residential and agriculture (described in Table $1 \mathrm{~b}$ underneath). 


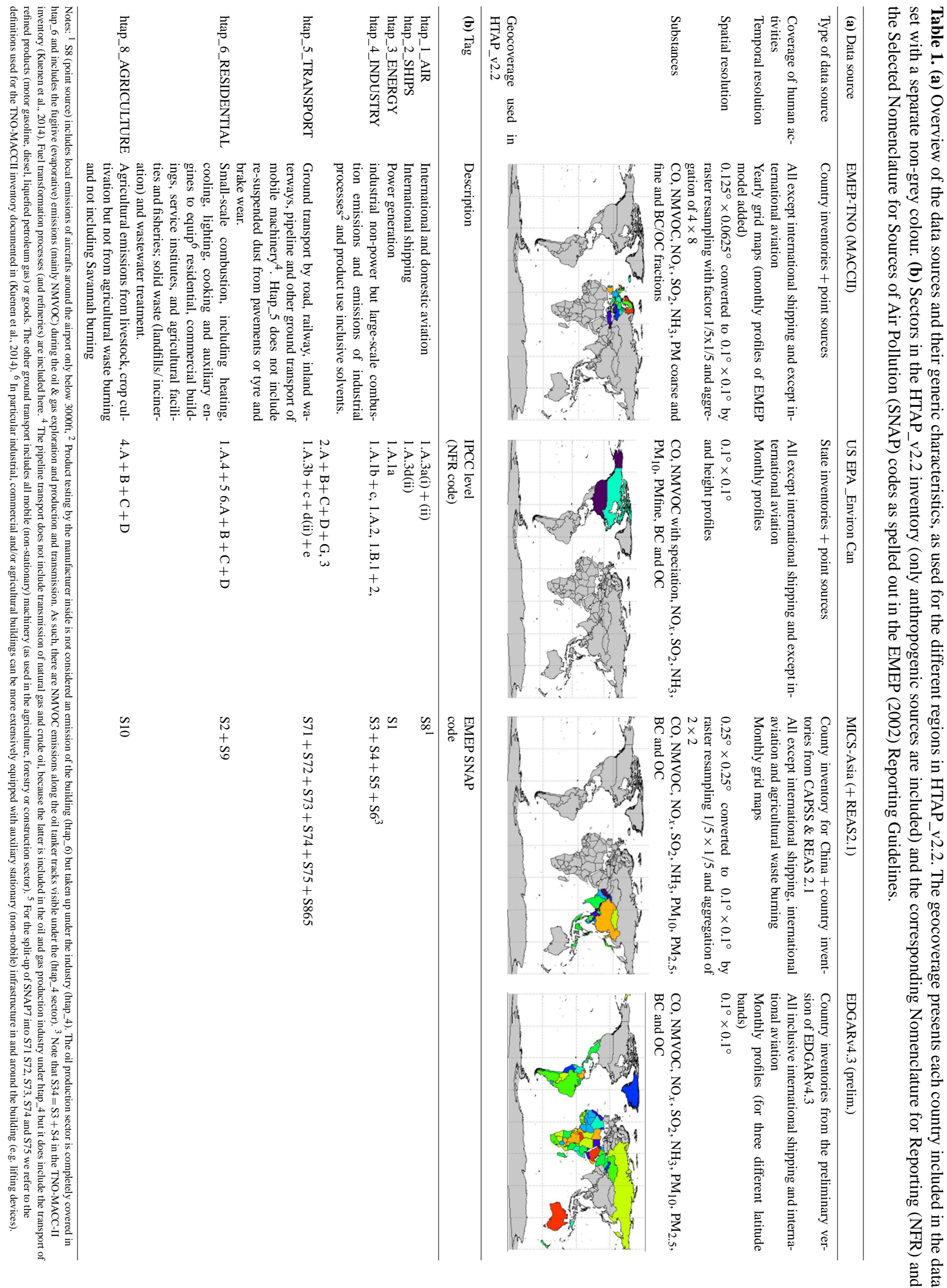


HTAP_v2.2 focusses only on anthropogenic emissions, in a comprehensive way, but excludes large-scale biomass burning (forest fires, peat fires and their decay) and agricultural waste or field burning. We refer to inventories such as GFED3 (van der Werf, 2010) for the forest, grassland and Savannah fires (IPCC categories $5 \mathrm{~A}+\mathrm{C}+4 \mathrm{E}$ ) and to the $1^{\circ} \times 1^{\circ}$ grid maps of Yevich and Logan (2003) or the $0.1^{\circ} \times 0.1^{\circ}$ EDGARv4.2 grid maps (EC-JRC/PBL, 2011) for the agricultural waste burning $(4 \mathrm{~F})$. Moreover, only $\mathrm{NH}_{3}$ emissions from the agricultural sector were taken up in the htap_8_AGRICULTURE sector of HTAP_v2.2 inventory, so that the occasionally reported $\mathrm{NO}_{x}$ from agricultural waste burning or from biological $\mathrm{N}$ fixation and crop residues (which is typically considered under S10 for Europe) are excluded.

\subsection{Gridded input data sets for HTAP_v2.2}

As explained earlier, the goal of the HTAP_v2.2 inventory is to provide consistent and highly resolved information (see Fig. 1a) to global and regional modelling. It is important to realize that in the HTAP modelling exercise both global and regional models are participating. The HTAP global modelling is coordinated with the regional modelling exercise of Air Quality Model Evaluation International Initiative AQMEII (Galmarini et al., 2012, 2015) that manages regional scale activities for Europe and North America, and the regional modelling exercise of the Model Intercomparison study for Asia MICS-Asia (Carmichael et al., 2008) that manages the regional modelling over Asia. Hence, the regional inventories used for HTAP_v2.2 are constructed and used in accordance with these regional activities.

\subsubsection{USA and Canada: EPA and Environment Canada grid maps and EPA temporal profiles}

EPA (2013) provides the 2008 and 2010 areal and point source emissions for the complete North American domain at $0.1^{\circ} \times 0.1^{\circ}$ resolution, covering USA with a grid ranging from $180-63^{\circ} \mathrm{W}$ in longitude and $75-15^{\circ} \mathrm{N}$ in latitude and covering Canada with a grid from $142-47.8^{\circ} \mathrm{W}$ in longitude and $85-41^{\circ} \mathrm{N}$ in latitude. Mexico is not covered by these latitudes and it is gap-filled with EDGARv4.3 data (see Sect. 2.2.4). For the northern latitudes above $45^{\circ} \mathrm{N}$, Environment Canada provided the 2008 basis and an update of the point sources for 2010, from which US EPA prepared the full set of detailed grid maps also for 2010. The 2010 data for Canada were missing and as such extrapolated by US EPA based on the 2008 National Emission Inventory of Environment Canada and assuming no trend, but they use updated point sources (Pouliot et al., 2014). The temporal profiles of US EPA were applied for USA and Canada with identical monthly distributions per sector for 2008 and 2010. More details about the US inventory are given by Pouliot et al. (2014, 2015).

\subsubsection{Europe: TNO grid maps and EMEP temporal trends}

Countries that are parties to the CLRTAP (http://www.unece. org/env/lrtap/welcome.html) need to report anthropogenic emissions of air pollutants and particulate matter, but neither BC nor OC. These reported/official inventories are reported on the national level to EMEP-CEIP ${ }^{6}$ which provides the annual emission inventory data for $\mathrm{CO}, \mathrm{NH}_{3}, \mathrm{NMVOC}$, $\mathrm{NO}_{x}, \mathrm{SO}_{x}, \mathrm{PM}_{10}$ and $\mathrm{PM}_{2.5}$ (not $\mathrm{BC}$ and not $\mathrm{OC}$ ). However, the currently used EMEP grid uses a polar-stereographic projection with about $50 \mathrm{~km} \times 50 \mathrm{~km}$ grid cells centred over the European region and converting to a Mercator projection implied a loss of spatial accuracy. These reported data are incomplete according to the CEIP annual report of Mareckova et al. (2013) and for evaluation with the EMEP unified model further gap filling is needed, resulting in a semi-official emission data set. To overcome the problems of inconsistent emissions time series and fulfil the need for a higher spatial resolution to support AQ modelling in Europe in the European FP7 project Monitoring Atmospheric Composition and Climate (MACC), TNO established a scientifically complete and widely accepted data set, which is fully documented by Kuenen et al. (2014). This so-called TNO-MACC-II inventory of Kuenen et al. (2014) covers the same European domain with areal and point source emission grid maps at $1 / 8^{\circ} \times 1 / 16^{\circ}$ resolution for $\mathrm{SO}_{2}, \mathrm{NO}_{x}, \mathrm{CO}, \mathrm{NMVOC}, \mathrm{NH}_{3}$, $\mathrm{PM}_{10}, \mathrm{PM}_{2.5}$ with point sources allocated to their exact location. The grid-domain ranges from $30^{\circ} \mathrm{W}$ to $60^{\circ} \mathrm{E}$ in longitude and $72-30^{\circ} \mathrm{N}$ in latitude. The geographical area covered all EU-28 countries, Switzerland, Norway, Iceland and Liechtenstein, Albania, Bosnia-Herzegovina, Serbia, Macedonia, six Newly Independent States (Armenia, Azerbaijan, Belarus, Georgia, Moldova, Ukraine) and Turkey. EMEPTNO data for countries with only partial coverage (Russia, Turkmenistan, Kazakhstan and Uzbekistan) were not used in the HTAP_v2.2 inventory because of inconsistencies with other data sets (see Sect. 2.2.4). Sector-specific data (given by SNAP-code, see Table 1b) are used for all countries with complete coverage of their territory and for each substance the contribution from each sector is compared to EMEP and EDGARv4.3 estimates. Standard re-sampling is applied to obtain grid maps at the common resolution of $0.1^{\circ} \times 0.1^{\circ}$. Point-source, ground-level airport emissions in the transport sector (under SNAP 8) were taken out, in order to avoid a double counting with the aviation sector (HTAP1_AIR), for which the same geospatial data set taken from EDGAR_v4.3 was used globally.

The EMEP-TNO data were only available for 2006 and 2009. The 2008 data for Europe are based on the EMEPTNO data for 2009 data, and the 2010 data for Europe are based on the same 2009 data but using the trend in EMEPTNO data between 2006 and 2009. For $\mathrm{NH}_{3}$, the reporting of

\footnotetext{
${ }^{6}$ More info on www.ceip.at.
} 


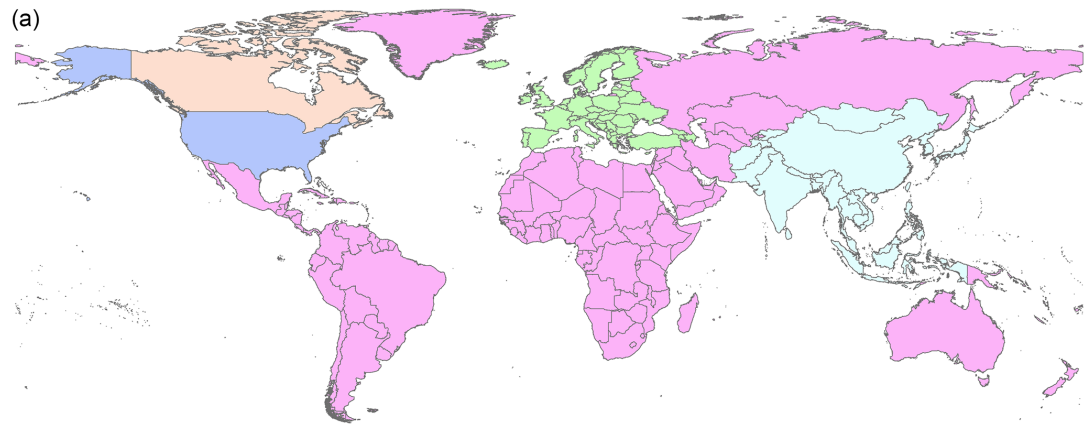

HTAP data sources

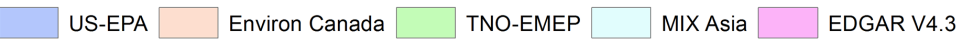

(b)

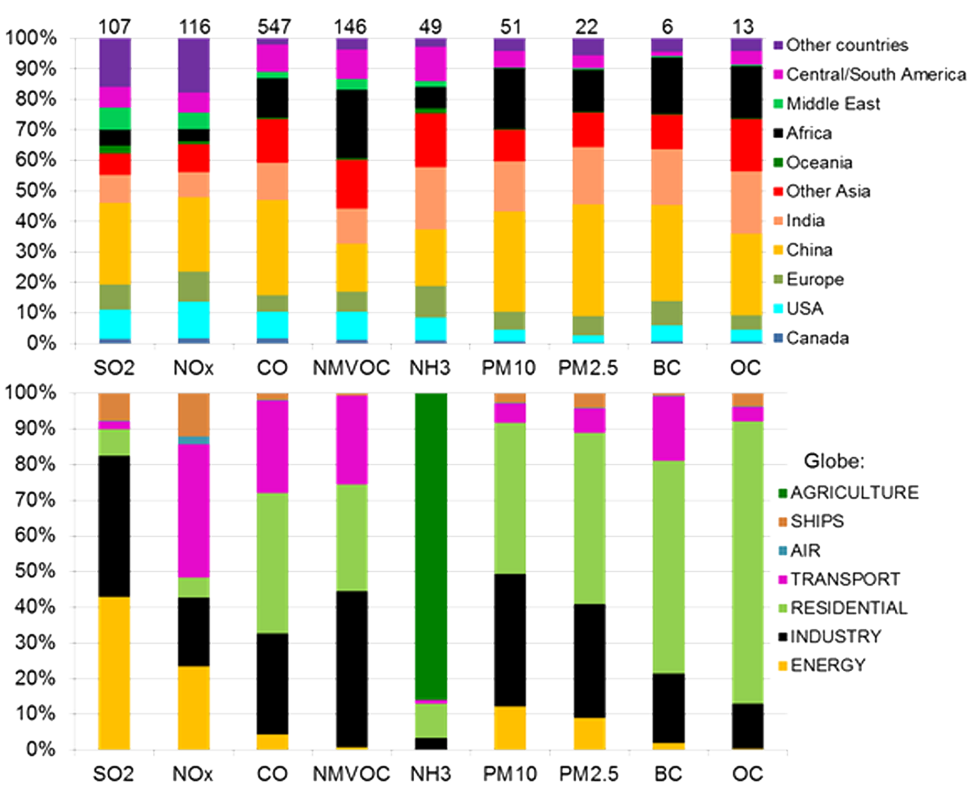

(c)
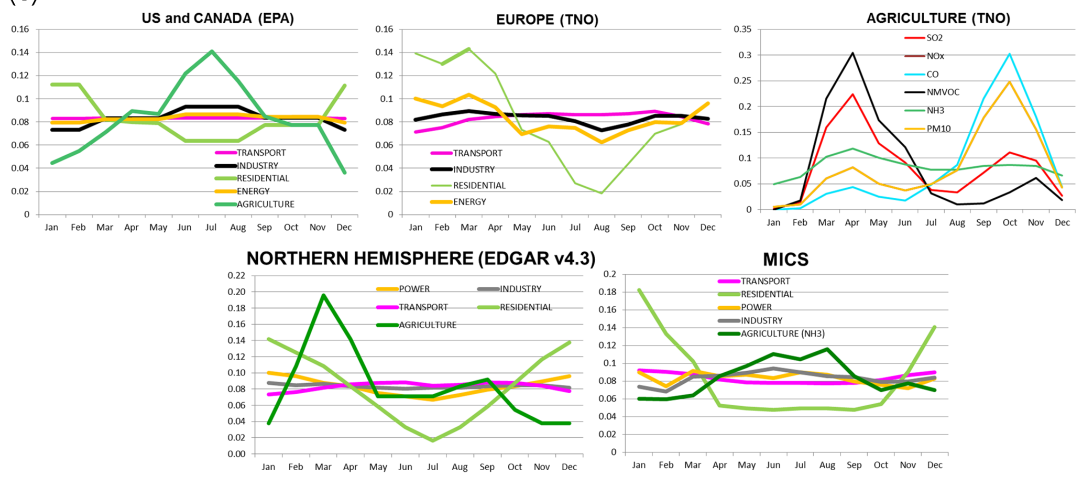

Figure 1. (a) Collection of regional emission inventories (US-EPA, Environ Canada, TNO-EMEP, MIX (MICS-Asia III), EDGARv4.3 for the global air pollutants and their use for world countries in data set HTAP v2.2 (b) Regional relative contribution to 2010 pollutant emissions (upper panel). Asian emissions have been divided into China, India and other Asia fractions from the MIX database. The region "rest of the world" has been disaggregated into Oceania, Africa, Middle East, Central/South America and other countries making use of the EDGAR v4.3 inventory. Global sector-specific anthropogenic emissions of gaseous pollutants and particulate matter components for the year 2010 (lower panel). Global absolute emissions are reported on top of each bar in Tg species per year. Large scale open-biomass burning is not included in the analysis. (c) Temporal profiles with relative factors varying around 1/12 and applied on the yearly emissions of the different data sources (US-EPA for US and Canada, EMEP-TNO for Europe with compound-specific variation of the agricultural temporal profiles, EDGAR temporal profiles for the Northern Hemisphere and MICS profiles for Asia). 
emissions from the energy, industry and residential sectors was apparently negligible for some countries ${ }^{7}$ compared to the agricultural emissions and was therefore not gap-filled by EMEP and/or TNO.

$\mathrm{BC}$ and $\mathrm{OC}$ emission data are not available as emission grid maps within the MACC-II data set, but the PM grid maps are accompanied by a recommendation on the PM composition describing the carbonaceous profiles per SNAP code and country. This so-called PM split table (per SNAP code and country) of TNO (Visschedijk et al., 2009) is used to derive the $\mathrm{BC}$ and $\mathrm{OC}$ from $\mathrm{PM}_{10}$ and $\mathrm{PM}_{2.5}$ emission grid maps (see Kuenen et al. (2014) for details).

Finally, to derive the monthly grid maps the EMEP modelling group provided the monthly profiles, which are with a monthly factors varying around 0.0833 specified for each country and for each sector, with a further substance-specific variation for the agricultural sector (M. Schulz, personal communication, 27 May 2013 and A. Nyiri, personal communication, 4 June 2013).

\subsubsection{Asia: monthly grid maps from MIX}

For Asia, a different challenge is faced, because no countries except Japan are legally required to yearly report detailed emission inventories under the CLRTAP, UNFCCC or similar conventions. However, in Asia many scientific efforts aimed at establishing a detailed emission inventory, accepted by the different regions, using official or semi-official statistics collected at county level (by provinces for China). Under the Model Inter-comparison Study for Asia Phase III (MICSAsia III), a mosaic Asian anthropogenic emission inventory was developed for 2008 and 2010 (Li et al., 2015). The mosaic inventory, named MIX, incorporated several local emission inventories including the Multi-resolution Emission Inventory for China (MEIC), $\mathrm{NH}_{3}$ emission inventory from Peking University (Huang et al., 2012), Korean emissions from the Clean Air Policy Support System (CAPSS) (Lee et al., 2011), Indian emissions from the Argonne National Laboratory (Lu et al., 2011), and fill the gap where local emission data are not available using REAS2. $1^{8}$ developed by Kurokawa et al. (2013).

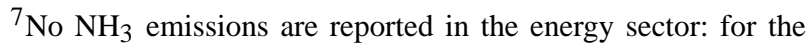
countries Albania, Bosnia-Herzegovina, Cyprus, Estonia, Greece, Ireland, Iceland, Luxembourg, Latvia, FRY Macedonia, Malta, Norway, Poland, Romania, Slovakia, and Slovenia; in the industry sector for the countries Albania, Bosnia-Herzegovina, Greece, Ireland, Iceland, and FRY Macedonia; and in the residential sector for the countries Greece, Iceland and Slovenia.

${ }^{8}$ The REAS2.1 inventory for Japan includes the data developed by Ministry of the Environment of Japan (MOEJ, 2009) for NMVOC evaporative emissions from stationary sources, the database developed by the Ocean Policy Research Foundation (OPRF, 2012) for the maritime sector, and the Japan Auto-Oil Program Emission Inventory-Data Base (JEI-DB) developed by Japan Petroleum Energy Center (JPEC, 2012a, b, c) for other sources.
}

MEIC is developed by Tsinghua University under an openaccess model framework that provides model-ready emission data over China to support chemical transport models and climate models at different spatial resolution and time scale. In the MIX inventory, the MEIC v.1.0 data were used, which contain the anthropogenic emissions of China for $\mathrm{SO}_{2}, \mathrm{NO}_{x}$, $\mathrm{CO}, \mathrm{NMVOC}, \mathrm{NH}_{3}, \mathrm{CO}_{2}, \mathrm{PM}_{2.5}$, PMcoarse, $\mathrm{BC}$, and $\mathrm{OC}$ for the years 2008 and 2010 with monthly temporal variation at $0.25^{\circ} \times 0.25^{\circ}$. For India, MIX used the Indian emission inventory provided by ANL (Argonne National Laboratory) for $\mathrm{SO}_{2}, \mathrm{BC}$, and $\mathrm{OC}$ and REAS2.1 for other species. With the input from different regions, the MIX inventory provided harmonized emission data at $0.25^{\circ} \times 0.25^{\circ}$ grid resolution with monthly variation for both 2008 and 2010. The detailed mosaic process of the MIX inventory is documented in $\mathrm{Li}$ et al. (2015). Reported emissions from countries which are only partly covered by the MIX, like Russia, Turkmenistan, Uzbekistan and Kazakhstan were not taken up in the HTAP inventory and instead gap filling by EDGARv4.3 was used (see Sect. 2.2.4).

As such, countries within the broad area, spanning from $89.875^{\circ} \mathrm{N}$ to $20.125^{\circ} \mathrm{S}$ in latitude and from 40.125 to $179.875^{\circ} \mathrm{E}$ in longitude were inserted in the $0.1^{\circ} \times 0.1^{\circ}$ emission grid maps after converting the $0.25^{\circ} \times 0.25^{\circ}$ with a raster resample procedure - dividing the cells in $5 \times 5$ and then aggregating the $0.05^{\circ} \times 0.05^{\circ}$ cells $2 \times 2$. Monthly grid map results (without distinction between point and areal sources and without temporal profiles) are given per sector (energy, industry, residential, transport, and agriculture only for $\mathrm{NH}_{3}$ ).

\subsubsection{Rest of the world covered by EDGARv4.3}

The Emission Database for Global Atmospheric Research (EDGAR) of EC-JRC/PBL (2011) provides historical (19702008) global anthropogenic emissions of greenhouse gases 9 $\mathrm{CO}_{2}, \mathrm{CH}_{4}, \mathrm{~N}_{2} \mathrm{O}, \mathrm{HFCs}, \mathrm{PFCs}$ and $\mathrm{SF}_{6}$, of precursor gases, such as $\mathrm{CO}, \mathrm{NO}_{x}, \mathrm{NMVOC}$ and $\mathrm{SO}_{2}$ and of aerosols $\left(\mathrm{PM}_{10}\right)$ per source category at country level on $0.1^{\circ} \times 0.1^{\circ}$ grid maps. This data set is in the version EDGARv4.3 extended with the years 2009 and 2010 and covering with the carbonaceous species $\mathrm{PM}_{2.5}, \mathrm{BC}$ and OC. For HTAP_v2.2 a preliminary version of the EDGARv4.3 (EC-JRC/PBL, 2015) is used. Emissions are calculated by taking into account human activity data of IEA (2013) for fuel consumption and of FAO (2012) for agriculture, different technologies with installed abatement measures, uncontrolled emission factors (IPCC, 2006) and emission reduction effects of control measures (EMEP/EEA, 2013). Anthropogenic emissions calculations are extended till 2010 for all 246 world countries for the emission source (sub)groups; (i) combustion/conversion in energy industry, manufacturing industry, transport and res-

\footnotetext{
${ }^{9}$ The methodology for the greenhouse gas emission time series applied in EDGARv4.2 is detailed in Olivier and JanssensMaenhout (2012).
} 
idential sectors, (ii) industrial processes, (iii) solvents and other product use, (iv) agriculture, (v) large scale biomass burning, (vi) waste and (vii) miscellaneous sources.

The EDGAR emission data are spatially distributed using an extensive set of global proxy data, which are representative for major source sectors and documented in the EDGAR gridding manual of Janssens-Maenhout et al. (2013). For HTAP_v2.2, the EDGARv4.3 database provides yearly emission grid maps with a resolution of $0.1 \times 0.1$ degree for the "rest of the world" countries of Table S1.2 of Annex I in the Supplement for all pollutants $\left(\mathrm{SO}_{2}, \mathrm{NO}_{x}, \mathrm{CO}, \mathrm{NMVOC}\right.$, $\mathrm{NH}_{3}, \mathrm{PM}_{10}, \mathrm{PM}_{2.5}, \mathrm{OC}, \mathrm{BC}$ ) and HTAP sectors for the years 2008 and 2010. The htap_2 SHIPS data are provided for the entire world, while the htap_1 AIR data are provided for the entire world for the international aviation and for the world excluding USA and Canada for the domestic aviation. EDGAR provides also sector-specific monthly profiles, defined with first order estimated factors for each of the three different zones: Northern Hemisphere, the Equatorial region and Southern Hemisphere (Table S1.2 in the Supplement). A reverse profile is applied for the two hemispheres from the EDGAR v4.3 database, while no seasonal pattern is used for the Equatorial regions. Monthly emissions grid maps are generated from the annual emission data per HTAP sector using these EDGAR monthly factors, which resemble most to the EMEP-TNO profiles (see Sect. 2.3).

The countries with partial geo-spatial coverage under the MACC-II and MIX inventories (see Sects. 2.2.2 and 2.2.3) are completely replaced with EDGARv4.3 data to avoid inconsistencies and artefacts at the border between two data sets within one country (such as Russia, Kazakhstan, Turkmenistan and Uzbekistan). This replacement took place after the grid maps were converted into $0.1^{\circ} \times 0.1^{\circ}$ using a raster resampling procedure. For EMEP-TNO the resampling implied a 25 -fold division to $0.0025^{\circ} \times 0.0125^{\circ}$ followed by an aggregation of $4 \times 8$ grid cells. For MIX the resampling needed also a 25 th fold division to $0.05^{\circ} \times 0.05^{\circ}$ followed by an aggregation of $2 \times 2$ grid cells. The cells including country borders are split up and allocated to the different countries using the corresponding areal percentage.

\subsection{Overview of the temporal profiles used in HTAP_v2.2}

The modulation of annual emissions over time is necessary in order to provide the modelers emission data consistent with the seasonal pattern and activities. Monthly data were generated for all sectors except for the international shipping and international aviation, which are considered constant over the year. US-EPA, EMEP and EDGAR provided monthly profiles, but MIX provided directly and solely monthly emission grid maps.

Figure 1c summarizes the sector-specific monthly profiles for each of the regional data sets. The temporal profiles are additive and specified with monthly factors mod- ulating around $1 / 12$ for each of the sectors. For the agricultural sector, EMEP provided compound-specific monthly factors, which characterise high NMVOC emission in spring and high $\mathrm{CO}$ emission in autumn. Agriculture (largely contributing to $\mathrm{NH}_{3}$ emissions) shows most seasonal variation, which differs also most between the different regions because of region-specific management practices (for e.g. crop cultivation), climate and geographical location and soil composition. The residential sector is characterized by a monthly distribution which is inversely related with the temperature and therefore with the use of heating systems, and in some developed countries with air conditioning. In some developed countries with hot summers, air conditioning again boosts emissions during the summer. The seasonality remains relatively modest in all regions for the sectors transport, industry and energy.

The strongest variation over the year and between regions is observed for the agricultural sector $(+215 \%$ in the EMEPTNO profiles but only $+45 \%$ in the MIX profiles), followed by the residential sector $((+70$ and $-75 \%)$ in the EMEPTNO profiles, $(+20$ and $-25 \%)$ in the US EPA profiles and $(+115$ and $-40 \%)$ in the MIX profiles).

\section{Results}

Monthly global grid maps were produced for 2008 and 2010 and are available per HTAP sector and substance at http://edgar.jrc.ec.europa.eu/htap_v2/index.php? $\mathrm{SECURE}=\_123$. We describe major characteristics of the grid maps in Sect. 3.1. We focus on 2010 but the observations remain valid for 2008 (in the same period of recession). A summary graph of the emission totals and their sectorspecific composition is given in Fig. 1b. In Sects. 3.2 and 3.3 we put the country totals (given bottom-up except for the MICS-Asia regions, where we derived the totals from the grid maps) in perspective with a comparative analysis of the emissions per capita and emissions per GDP for low, lower middle, upper middle and high income country groups. To estimate how polluting the activities are in the different regions, Sect. 3.4 addresses the implied emission factors. Finally, we address the difference in emissions 2008 to 2010 in Sect. 3.5, and we conclude with a qualitative assessment of the uncertainty of the grid maps in 3.6.

\subsection{Spatial distribution of global emissions per sector}

An overview on the region-specific totals and the composition per region and sector is given in the nine maps of Fig. 2a-i for the different substances for the year 2010. The sector-specific country-totals are given in Table S1.1 and the totals for each of the 16 HTAP source region, as defined for the source-receptor calculations of the HTAP modelling community and described in Supplement Table S2.1 are given in Table S2.2 of Annex II in the Supplement. Be- 
fore focusing on the emissions over land surface, we assess the global shipping emissions. Table 2 a compares the international shipping emissions with the bottom-up and topdown estimated emissions reported by IMO (International Maritime Organisation) (2014). We note that an agreement between the data of HTAP (EDGAR based), and IMO (both top down and bottom up estimates) is obtained for all compounds within $30 \%$, except for CO. For the latter EDGAR shows a 55 and $70 \%$ higher estimate for the 2008 and 2010 bottom-up values of the IMO (2014) study, which on his turn is $55 \%$, respectively, $33 \%$ higher than the 2008 and 2010 top down estimates of the IMO (2014) study. It is worth mentioning that a $250 \%$ downscaling of the $\mathrm{CO}$ emission factor was undertaken in IMO (2014) compared to the previous study of IMO (2009).

Developing countries contribute from $70 \%$ to more than $90 \%$ to the current global anthropogenic pollutant emissions, depending on the considered compound and Asian countries are the major emitters, contributing from 40 to $70 \%$. Among these countries, China and India represent two densely populated regions, producing together more than two-thirds of the total Asian emissions. On the contrary, developed regions (like North America and Europe) produce much lower emissions, representing overall from 30 down to $10 \%$ of the total annual global anthropogenic emissions. Since the rest of the world group of countries includes a variety of regions, differing in population, human activities, types of industries, etc., it is crucial to disaggregate it into its components. In particular for $\mathrm{PM}_{2.5}$ and somewhat less for $\mathrm{NO}_{x}$, Asia strongly contributes to the global emissions compared to the contribution of North America and Europe.

Generally, higher emissions are observed for populated areas and coastal regions, but specific features can be highlighted depending on the pollutant and activity for specific countries per substance. The differences of the Figs. $2 \mathrm{a}-\mathrm{i}$ in the sector-specific composition (pie charts) of the emission sources for world regions (represented by the colour scale) vary strongly between compounds. Some of the factors include:

- for $\mathrm{SO}_{2}$ the emissions will depend on the importance of coal used in the industry and residential sectors and the degree of flue gas desulfurization. In some regions non-ferrous metals industry will be of great importance.

- For $\mathrm{NO}_{x}$ emissions industrial combustion and transport are key and with increasing level of activity the application of end-of-pipe controls, including catalytic reduction of flue gases, is playing an ever increasing role.

- CO and NMVOC emissions are dominated by incomplete combustion (cooking and heating stoves) and transport, especially in absence of advanced controls. For NMVOC additionally evaporative losses from solvent use and oil industry are of high relevance.
- Finally for PM, incomplete combustion (stoves) and in developing countries poor efficiency of filters installed on industrial boilers can be a source of large emissions while more recently transport emissions from diesel engines became of concern.

\subsection{1 $\mathrm{SO}_{2}$}

The Asian region is still characterised by a relatively large contribution of $\mathrm{SO}_{2}$ from (coal fired) power plants and manufacturing industry. Most of the $\mathrm{SO}_{2}$ emitted in North America and Europe comes from coal power plants. However, in Europe Fig. 2a shows that $\mathrm{SO}_{2}$ is also emitted from the residential and waste disposal sector. Residential (heating and cooking) and waste disposal sources are particularly relevant in Africa. High annual $\mathrm{SO}_{2}$ emissions are also observed for India, to which the energy sector contributes $59 \%$ and the energy-intensive manufacturing industry (iron and steel) $32 \%$, also both using coking and bituminous coal according to IEA (2013). Finally, international shipping contributes $\sim 10 \%$ to the global $\mathrm{SO}_{2}$ emissions. $\mathrm{SO}_{2}$ grid maps clearly show the ship emission tracks connecting Asia and Europe with Africa and America.

\subsubsection{NO $_{x}$}

Figure $2 \mathrm{~b}$ shows that the major sources of $\mathrm{NO}_{x}$ are ground transport and power generation and these source contributions show a rather uniform feature for all the considered regions. In Central and South America, major emissions are attributed to the transportation sector and just to a minor extent to the energy sector (e.g. in Mexico $65 \%$ of the $\mathrm{NO}_{x}$ emissions originate from road transport). Those industrialised countries with a large share of natural gas as fuel for heating houses and commercial centres and for industry (such as Canada, the Netherlands, Norway) show relatively high emissions of $\mathrm{NO}_{x}$ : the share of the residential and industry $\mathrm{NO}_{x}$ emissions is around $30 \%$ of the total $\mathrm{NO}_{x}$, whereas in USA this is only $20 \%$. International shipping and, in particular, aviation contribute together more than $10 \%$ of global $\mathrm{NO}_{x}$ emissions.

\subsubsection{CO}

$\mathrm{CO}$ is a product of incomplete combustion, which can therefore be emitted by any fuel combustion (ground transport, industrial processes involving combustion, as well as domestic heating). As presented in Fig. 2c, the power generation sector emits less $\mathrm{CO}$ than the residential one because of higher combustion efficiency and higher temperatures compared to domestic burners. In Africa, there are large emissions of $\mathrm{CO}$ from the residential sector, mainly due to the use of wood and charcoal for cooking activities. As shown in Fig. 2c, some industrial activities emit $\mathrm{CO}$, like the production of nonmetallic minerals and crude steel and iron, which is partic- 

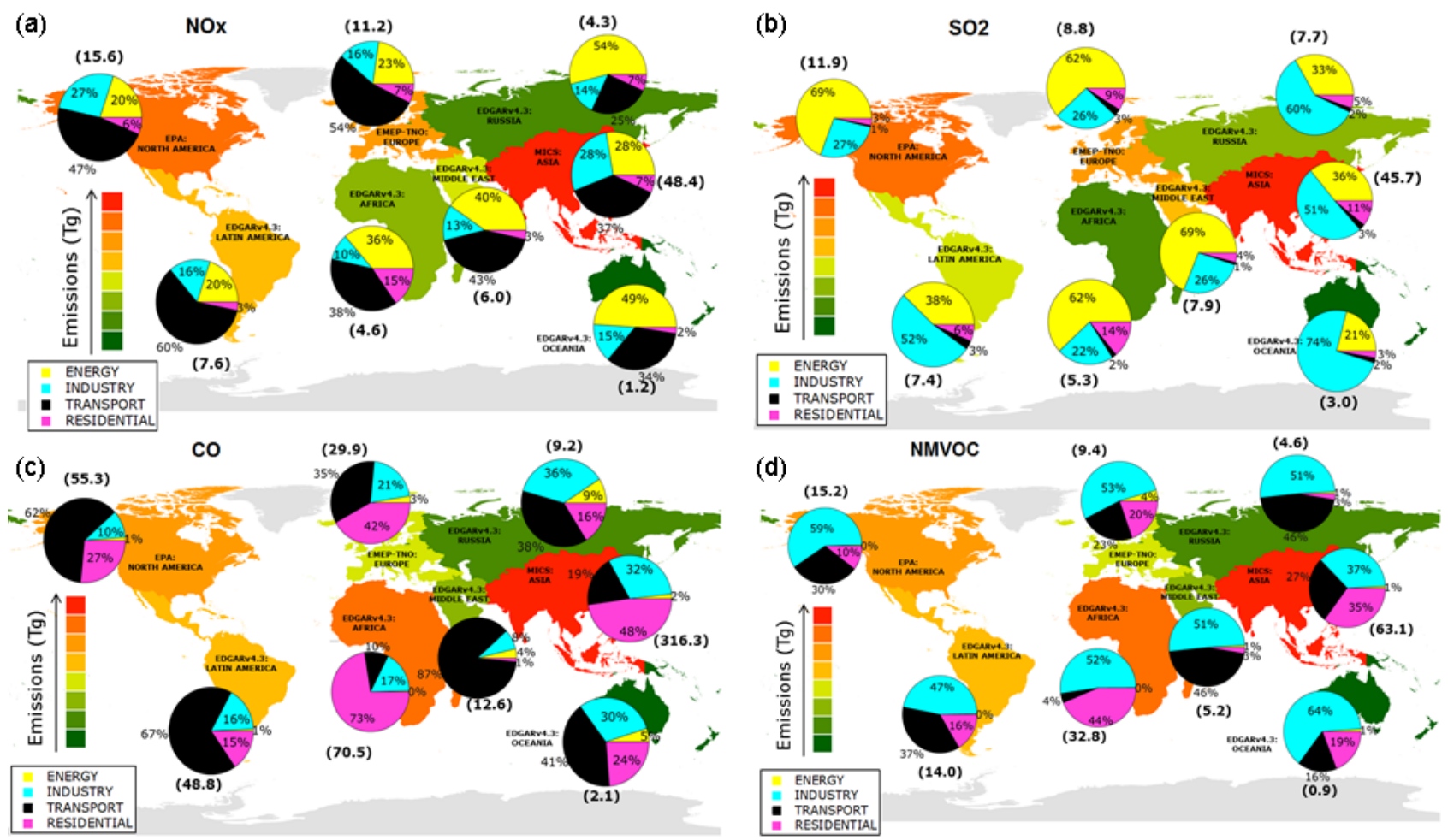

Figure 2.

ularly relevant for India and China, while non-ferrous metal and iron and steel production are dominant in Oceania.

\subsubsection{NMVOC}

NMVOCs (non-methane volatile organic compounds) are emitted from chemical and manufacturing industries, as well as fuel transformation processes, the production of primary fuels, the use of solvents and from the residential sector, inclusive waste (Fig. 2d). Important sources of NMVOCs include also evaporative emissions from road transport, specifically gasoline engines and the use of biofuels. Major emission sectors in the USA emitting NMVOCs include oil refineries, oil and gas production, several industrial processes and motor vehicles. Most of the NMVOC emissions in Europe are due to solvent use, road transport, and the use of primary solid biomass in the residential sector. In the Middle East, NMVOC sources include oil production: the industry sector in Saudi-Arabia contributes $75 \%$ to its total NMVOC emissions. In China, particularly high emissions are originating from industry $(62 \%)$ and residential $(27 \%)$, the latter also associated with the high usage of solvents in paints. In Brazil, particularly high usage of biogasoline is present resulting in a $52 \%$ NMVOC contribution of the transport sector. Also the production of charcoal is emitting strongly NMVOC and the world's top three emitters (IEA, 2013) are
Brazil, Thailand ${ }^{10}$ and Kenya, which explains that their industry sector is contributing to the NMVOC total with, respectively, 35, 37 and $80 \%$ in 2010. NMVOC speciation is not provided by the HTAP_v2.2 emission database; however, TNO has produced a breakdown into 23 NMVOC species, which has been used for the RETRO project and the RCP scenarios of IPCC AR5. Recommendations for the NMVOC splits are given on the HTAP wiki site http://iek8wikis.iek. fz-juelich.de/HTAPWiki/WP1.1.

\subsection{5 $\quad \mathrm{NH}_{3}$}

$\mathrm{NH}_{3}$ is mainly emitted by the agricultural sector, including management of manure and agricultural soils (application of nitrogen fertilizers, including animal waste), as Fig. $2 \mathrm{i}$ shows, while a relatively small amount is emitted by the deployment of catalysts in gasoline cars. Minor contributions are also observed for Asian countries from the residential sector due to dung and vegetable waste burning and coal combustion. For industrialized regions, especially for countries using low sulphur fuel, Mejía-Centeno et al. (2007) reported that the deployment of catalytic converters in gasoline cars enhanced the $\mathrm{NH}_{3}$ emissions from this source since mid2000. This is also observed by the larger $\mathrm{NH}_{3}$ with increased transport activity and corresponding increased consumption

\footnotetext{
${ }^{10}$ No charcoal production emissions are accounted for in the REAS2.1 inventory, which is a shortcoming mainly for Thailand.
} 


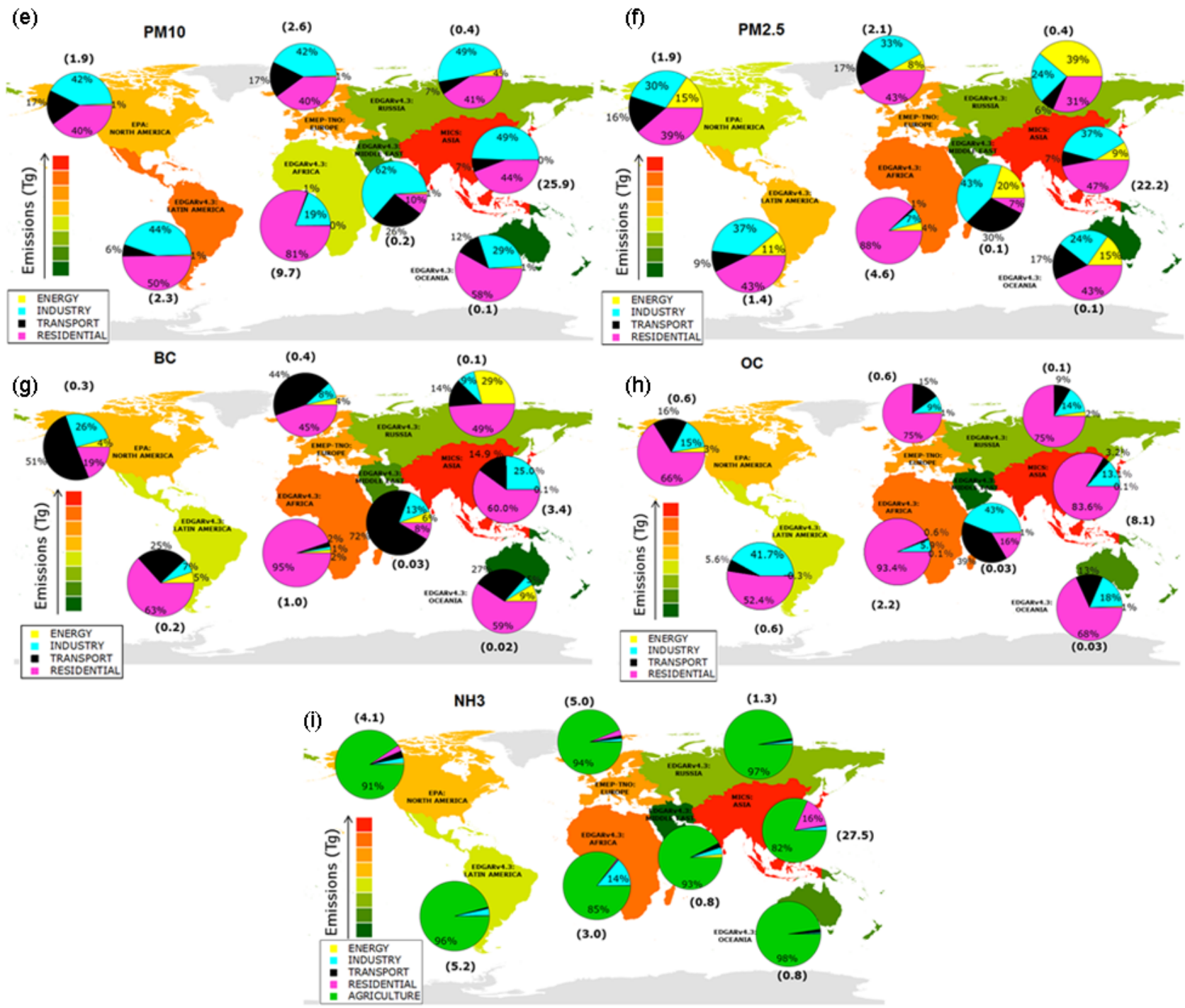

Figure 2. Sector-specific breakdown of regional emission totals (Tg) for 2010: (a) $\mathrm{SO}_{2}$, (b) $\mathrm{NO}_{x}$, (c) $\mathrm{CO}$, (d) $\mathrm{NMVOC},(\mathbf{e}) \mathrm{PM}_{10}$, (f) $\mathrm{PM}_{2.5}$, (g) $\mathrm{BC}$, (h) $\mathrm{OC}$ and (i) $\mathrm{NH}_{3}$.

of low sulphur fuels. In the USA gasoline vehicle catalysts represent ca $6 \%$ of total $\mathrm{NH}_{3}$ emissions, while a lower contribution is found for Europe due to the high deployment of diesel vehicles.

\subsection{6 $\mathrm{PM}_{10}$ and $\mathrm{PM}_{2.5}$}

Particulate matter (PM), both in the fine and coarse fraction, is mainly emitted by biomass and fossil fuel combustion in domestic and industrial activities (Fig. 2e and f). On the contrary, ground transportation contributes $\sim 5 \%$ to total PM emissions (excluding non-exhaust road abrasion dust and tyre wear emissions). As depicted in Fig. 1b, developed countries (like USA and EU) represent $\sim 10 \%$ of global emissions of PM and its components, while much higher contributions derive from developing countries where less strict legislation is applied in the industrial sector and in road transport. Figure $2 \mathrm{e}$ and $\mathrm{f}$ show a similar composition of the contributing sectors to $\mathrm{PM}_{10}$ and $\mathrm{PM}_{2.5}$ globally. $\mathrm{PM}_{10}$ and $\mathrm{PM}_{2.5}$ grid maps point out the enhanced $\mathrm{PM}$ emissions in Asian countries, due to industrial processes and the residential sector. A decreasing trend from 2008 to 2010 is observed for Brazil due to decreases in emissions from charcoal production (with $23 \%$ share in the world production in 2008 and $12 \%$ in 2010, according to IEA, 2013). Emissions from charcoal production are also important for some African countries (Kenya, Sudan, South Africa, Tanzania, Ethiopia), with country-specific shares in world production varying between 1.3 and $12.9 \%$ according to IEA (2013). Western Africa generally emits more PM than the eastern part because of more industrial activities. 
Table 2. (a) Comparison of the international shipping emissions: IMO bottom-up (BU) and IMO top-down (TD) emissions of the IMO (2014) study and the EDGAR emissions of the HTAP_v2.2 (2015) study. (b) Per capita emissions in 2010 for USA, Germany, China, India, Russia and Japan from HTAP_v2.2. (c) Emissions per unit of GDP in 2010 for USA, Germany, China, India, Russia and Japan from HTAP_v2.2.

\begin{tabular}{|c|c|c|c|c|c|c|c|c|}
\hline (a) kton $\mathrm{yr}^{-1}$ & $\mathrm{BC}$ & $\mathrm{CO}$ & NMVOC & $\mathrm{NO}_{x}$ & $\mathrm{OC}$ & $\mathrm{PM}_{10}$ & $\mathrm{PM}_{2.5}$ & $\mathrm{SO}_{2}$ \\
\hline EDGAR 2008 & 34 & 1340 & 730 & 13762 & 458 & 1376 & 1376 & 8348 \\
\hline IMO BU 2008 & & 864 & 727 & 20759 & & 1545 & 1545 & 11041 \\
\hline IMO TD 2008 & & 553 & 615 & 18442 & & 1221 & 1400 & 8280 \\
\hline EDGAR 2010 & 33 & 1300 & 720 & 14000 & 430 & 1400 & 1400 & 8300 \\
\hline IMO BU 2010 & & 763 & 593 & 16708 & & 1332 & 1332 & 9895 \\
\hline IMO TD 2010 & & 574 & 638 & 19098 & & 1304 & 1304 & 9232 \\
\hline (b) Substance & USA & Germany & China & India & Russia & Japan & & \\
\hline 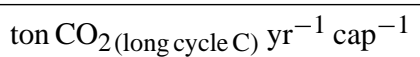 & 17.6 & 9.9 & 6.4 & 1.5 & 11.9 & 9.7 & & \\
\hline HDI & 0.91 & 0.90 & 0.70 & 0.57 & 0.77 & 0.88 & & \\
\hline $\mathrm{kg} \mathrm{SO}_{x} \mathrm{yr}^{-1} \mathrm{cap}^{-1}$ & 32.6 & 5.2 & 21.0 & 8.0 & 31.9 & 5.2 & & \\
\hline $\mathrm{kg} \mathrm{NO}_{x} \mathrm{yr}^{-1} \mathrm{cap}^{-1}$ & 43.6 & 14.2 & 20.8 & 7.9 & 25.1 & 14.5 & & \\
\hline $\mathrm{kg} \mathrm{NMVOC}^{-1} \mathrm{yr}^{-1} \mathrm{cap}^{-1}$ & 43.1 & 11.9 & 16.9 & 14.0 & 26.9 & 9.1 & & \\
\hline $\mathrm{kgCO}^{-1} \mathrm{yr}^{-1} \mathrm{cap}$ & 148.3 & 35.6 & 125.6 & 56.0 & 52.8 & 33.1 & & \\
\hline $\mathrm{kg} \mathrm{NH}_{3} \mathrm{yr}^{-1} \mathrm{cap}^{-1}$ & 11.6 & 7.3 & 6.7 & 8.2 & 6.3 & 3.7 & & \\
\hline $\mathrm{kg} \mathrm{PM}_{2.5} \mathrm{yr}^{-1} \mathrm{cap}^{-1}$ & 5.25 & 1.08 & 8.93 & 5.19 & 2.18 & 0.62 & & \\
\hline $\mathrm{kg} \mathrm{BC}^{-1} \mathrm{yr}^{-1} \mathrm{cap}^{-1}$ & 0.95 & 0.20 & 1.29 & 0.85 & 0.29 & 0.16 & & \\
\hline (c) Substance & USA & Germany & China & India & Russia & Japan & & \\
\hline 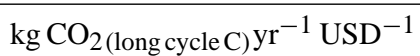 & 339.71 & 287.79 & 240.88 & 136.6 & 644.58 & 267.08 & & \\
\hline $\mathrm{GDP}_{\mathrm{cap}^{-1}}$ & 49307 & 39668 & 9230 & 4638 & 21663 & 34561 & & \\
\hline $\mathrm{g} \mathrm{SO}_{x} \mathrm{yr}^{-1} \mathrm{USD}^{-1}$ & 0.668 & 0.132 & 2.310 & 1.719 & 1.482 & 0.150 & & \\
\hline $\mathrm{g} \mathrm{NO}_{x} \mathrm{yr}^{-1} \mathrm{USD}^{-1}$ & 0.892 & 0.363 & 2.295 & 1.714 & 1.166 & 0.419 & & \\
\hline 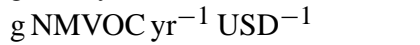 & 0.882 & 0.305 & 1.863 & 3.013 & 1.249 & 0.263 & & \\
\hline $\mathrm{g} \mathrm{CO} \mathrm{yr}^{-1} \mathrm{USD}^{-1}$ & 3.036 & 0.910 & 13.830 & 12.069 & 2.449 & 0.957 & & \\
\hline $\mathrm{g} \mathrm{NH}_{3} \mathrm{yr}^{-1} \mathrm{USD}^{-1}$ & 0.236 & 0.187 & 0.735 & 1.770 & 0.291 & 0.108 & & \\
\hline $\mathrm{g} \mathrm{PM}_{2.5} \mathrm{yr}^{-1} \mathrm{USD}$ & 0.108 & 0.028 & 0.984 & 1.119 & 0.101 & 0.018 & & \\
\hline $\mathrm{g} \mathrm{BC} \mathrm{yr}^{-1} \mathrm{USD}^{-1}$ & 0.019 & 0.005 & 0.143 & 0.183 & 0.013 & 0.004 & & \\
\hline
\end{tabular}

\subsubsection{BC and OC}

Black carbon (BC), the light-absorbing component of the carbonaceous part of PM, and organic carbon (OC) are emitted from incomplete combustion. Major emission sources are residential cooking and heating (fossil fuel and biomass combustion) and for BC also ground transport (especially diesel engines). Very low emissions originate from the energy sector due to higher process efficiencies and high combustion temperatures. Figure $2 \mathrm{~g}$ shows that the largest contributing sector for BC in North America, Europe and the Middle East is road transport, which can be allocated mainly to diesel vehicles given the much higher $\mathrm{BC}$ emission factor for diesel than for petrol. Heavy duty and light duty vehicles in these regions, as well as diesel passenger cars in Europe and the Middle East, cause this relatively large contribution despite the use of particle filters, which have not yet fully penetrated the fleet. For Asia, Oceania, Africa and Central and South America, the residential sector is the main contributor of $\mathrm{BC}$ emissions. In China and India the industry and residential sectors contribute to, respectively, 84 and $91 \%$ of their total BC emissions, while this share in USA or in Germany is only $42 \%$ and $36 \%$, respectively. The IEA (2003) data indicates the combination of high usage of coal (mainly in China) and of biomass (mainly for India) in power plants, coke ovens and non-metallic mineral industries, as well as the residential heating. The residential sector in China accounts for more than half $(52 \%)$ of its BC total. Russia shows a similar high share of the residential sector $(46 \%)$ to its total BC. Most important sources calculated in EDGARv4.3 for heating buildings in Russia include bituminous coal $(57 \%)$ and solid biomass (30\%), lignite (6\%) and industrial waste (3\%) burning in the residential sector (for domestic housing as well as commercial services) (EC-JRC/PBL, 2011 and IEA, 2013). A different situation is observed for Africa, where in addition to emissions from traffic and oil production, an important role is played by charcoal production and the use of primary solid biomass and charcoal in the residential sector. Nigeria has high flaring emissions from oil and gas production and Kenya and Sudan suffer from large 
charcoal production activities. For OC (Fig. 2h), all regions except the Middle East show that the largest emission contribution comes from the residential sector (combustion of charcoal and solid biomass). For the Middle East a relatively large contribution from industrial activities (fuel production) is observed.

\subsection{Per capita emissions}

To compare emissions from worldwide countries characterized by different degrees of development and numbers of inhabitants, per capita emissions were calculated. Countryspecific per capita total emissions are given in Table S3.1 of Annex III in the Supplement. In Table $2 b$ we compare for the world's top six $\mathrm{CO}_{2}$ emitters, China, USA, India, Russia, Japan and Germany the per capita air pollutant emissions while making the link with the country's activity level and level of clean technologies development. Country total population data were obtained from the United Nations Population Division (UNPD, 2013). This approach allocates the emissions from industrial production to a country without taking into account exports. No life cycle assessment of products at the point of consumption is considered here. This production-based approach has limitations as moving heavy industry from industrialized to developing countries puts a large burden on countries (in particular those with small populations and mining/manufacturing activities for export). For example mining for export is having a growing impact in Oceania (with low population) and industrial production in China for international markets became increasingly important since 2002 when China entered the World Trade Organisation. The importance of this consumption vs. production-based approach can be expected in 2008 (and also 2010) to be at least but probably even larger than what Boitier (2012) and Davis et al. (2011) amongst others reported for $\mathrm{CO}_{2}$. A consumption-based approach would yield at least $10 \%$ higher emissions for industrialised countries whereas $10 \%$ lower emissions for developing countries with emerging economy.

For $\mathrm{SO}_{2}$ the per capita emission in 2010 for EU-28 of $9.1 \mathrm{~kg} \mathrm{SO} \mathrm{Sap}^{-1}$ is very close to the reported value of $8.9 \mathrm{~kg} \mathrm{SO}_{2}$ cap $^{-1}$ from EuroSTAT (2014) - the 0.2 difference is much less than the $20 \%$ higher per capita $\mathrm{SO}_{2}$ emission in 2008 (11.5 kg SO 2 cap $\left.^{-1}\right)$. EU's $9.1 \mathrm{~kg} \mathrm{SO}_{2} \mathrm{cap}^{-1}$ is about half the $\mathrm{SO}_{2}$ per capita for China in 2010 and about one-third of the $\mathrm{SO}_{2}$ per capita for USA. Significant reductions of the Chinese $\mathrm{SO}_{2}$ per capita emissions started due to the introduction of very strict emission limits followed by ambitious flue gas desulfurization programs in power plants (Lu et al., 2011; Klimont et al., 2013; Wang et al., 2014). China is expected to follow the European example, where the $\mathrm{SO}_{2}$ per capita decreased from 1995 to 2005 with $65 \%$ of the decrease occurring in Germany and UK according to Ramanathan and Feng (2009).
For $\mathrm{NO}_{x}$ and NMVOC, China is similar to the European per capita levels. North America and Oceania double the level of European and Asian per capita emissions of $\mathrm{NO}_{x}$ and NMVOC for industrial combustion and transport mainly due to their larger fuel consumptions in the industry (Olivier et al., 2013) and road transport (Anderson et al., 2011) sectors, while having similar abatement technologies.

The level of per capita air pollution results from a combination of the per capita activity and the level of implementation of end-of-pipe measurement technology. The activity level can be reflected by the per capita $\mathrm{CO}_{2}$ emissions, which is highest for USA explaining the high air pollutant emissions per capita. However, it is not India with the lowest $\mathrm{CO}_{2}$ per capita, but Japan and Germany that have the lowest per capita air pollutant emissions, because of the level of technology and end-of-pipe implementation. To measure the latter we apply a kind of surrogate variable: the Human Development Index (HDI) (2010) from UNDP (2015). This shows that Germany and Japan are more advanced and have therefore lower emissions per capita for all air pollutants (except $\mathrm{NH}_{3}$ for Germany) and for the PM. We observe that the PM emissions per capita of Japan $\left(0.16 \mathrm{kgPM}_{2.5} \mathrm{yr}^{-1} \mathrm{cap}^{-1}\right)$ are only $60 \%$ of those of Germany and Germany's one are about one-fifth of the per capita emissions of the USA, which are on their turn only $60 \%$ of the per capita $\mathrm{PM}_{2.5}$ for China. Table S3.1 indicates that developing countries, in particular those with emerging economies but not yet fully penetrated clean technologies and end-of-pipe measures, have enhanced PM per capita emissions (China -

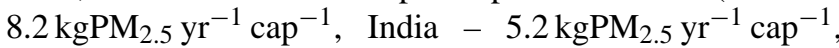
Brazil - $\left.3.1 \mathrm{kgPM}_{2.5} \mathrm{yr}^{-1} \mathrm{cap}^{-1}\right)$. Russia has relatively high per capita PM emissions $\left(2.2 \mathrm{kgPM}_{2.5} \mathrm{yr}^{-1}\right.$ cap $^{-1}$ because of fossil fuel production and consumption in the power sector,

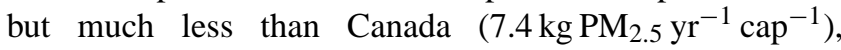
a much less populated country but with important fossil fuel production industry for export. Both countries, with important contribution in the Arctic region, show relatively high NMVOC and $\mathrm{SO}_{2}$ emissions (50.9 kg NMVOC yr ${ }^{-1} \mathrm{cap}^{-1}$ and $48.7 \mathrm{~kg} \mathrm{SO}_{2} \mathrm{yr}^{-1} \mathrm{cap}^{-1}$

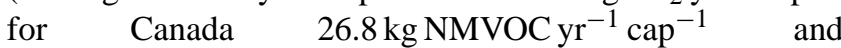
$31.9 \mathrm{~kg} \mathrm{SO}_{2} \mathrm{yr}^{-1} \mathrm{cap}^{-1}$ for Russia, respectively) due to their significant inland waterway transport using heavy residual fuel oil or diesel.

Figure 3 a gives an overview of the per capita emissions for high, upper and lower middle and low-income countries, as defined for the WGIII of AR5 of IPCC (2014). The largest variation between the different groups of countries is observed for $\mathrm{SO}_{2}$ and $\mathrm{NO}_{x}$, which represent the presence of industry. The median of per capita $\mathrm{SO}_{2}$ and $\mathrm{NO}_{x}$ emissions are higher for high and upper middle income countries than for low or lower middle income countries. The median of per capita CO and NMVOC is not strongly dependent on the income of the countries, whereas the median of per capita PM 
(and BC and OC) are definitely lower for high income countries than for low-income countries.

\subsection{Per GDP emissions}

Another indicator of emission intensity of a country is the ratio of emissions and gross domestic product (GDP) in USD, in constant purchasing power parity (PPP), as given in Table S3.2 of Annex III and shown in Fig. 3b. The GDP 2010 data for the different countries were obtained from World Bank (2014) and IMF (2014). This indicator is much more uncertain than the per capita emissions because the GDP is subject to heterogeneity (by the different economic activities), to heteroskedasticity (by time-dependent inflation and currency exchange rates) and to incompleteness (by the not officially reported activities). It is not recommended to use this per unit of GDP emissions indicator for relatively small countries with substantial service sectors (e.g. Luxembourg).

For 2010 Fig. 3b shows that EU and USA have similar low emissions per unit of GDP for all substances, except $\mathrm{NO}_{x}$ where EU's emission per unit of GDP is still significantly lower than in USA. China's emissions of $\mathrm{SO}_{2}$ and $\mathrm{NO}_{x}$ per unit of GDP are at the high end, whereas for $\mathrm{NH}_{3}$ and the carbonaceous particulate matter China is bypassed by India, which shows even higher emissions per unit of GDP. In analogy with Table $2 b$, Table $2 c$ provides for the world's top six $\mathrm{CO}_{2}$ emitters a comparison of the air pollutants per unit of GDP, which are linked to the country's economic activity (in GDP per capita) and $\mathrm{CO}_{2}$ per unit of GDP (measuring the energy intensive industry). It is directly apparent that again Germany and Japan are having high economic activity, with still important energy intensive industry but low air pollutant emissions per unit of GDP because of the investment in clean technology. On the other side, India has still much lower economic activity but nevertheless a much higher particulate matter emission per unit of GDP.

\subsection{Implied emission factors}

Energy-intensity is a widely used indicator to assess the fuel efficiency of manufacturing processes. Analogous to energy-intensity, we analyse in this section air pollution emission-intensity for all world countries. Emission intensity of economic activities for a given region are determined by implied emission factors. The region-specific implied emission factors (EFs) present the emissions per unit of activity (per TJ (terajoule) energy consumed for all combustion-related activities inclusive industrial processes or per 1000 head of animals for agricultural related activities) and are defined for a substance $x$ at year $t$ due to activities $\mathrm{AD}$ in activity subsectors $j, k$ of each of the main HTAP sectors (htap_3_ENERGY, htap_4_INDUSTRY, htap_5_TRANSPORT, htap_6_RESIDENTIAL, htap_8_AGRICULTURE) in a country $\mathrm{C}$ as follows:

$$
\begin{aligned}
& \operatorname{EF}_{\mathrm{C}, 3 \text { _energy }}(t, x)\left[\mathrm{kton}(\mathrm{TJ})^{-1}\right] \\
& =\frac{\left.\sum_{\text {sub sec torj }} \operatorname{EM}_{\mathrm{C}, 3 \_ \text {energy,j }}(t, x)\right|_{\text {data source of C }}}{\left.\sum_{\text {sub sec torj }} \mathrm{AD}_{\mathrm{C}, 3 \_ \text {_energy,j }}(t)\right|_{\text {EDGARv4.3 }}}
\end{aligned}
$$
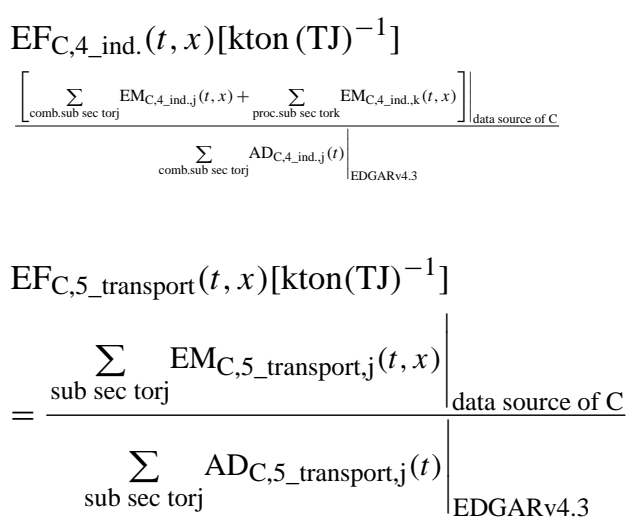

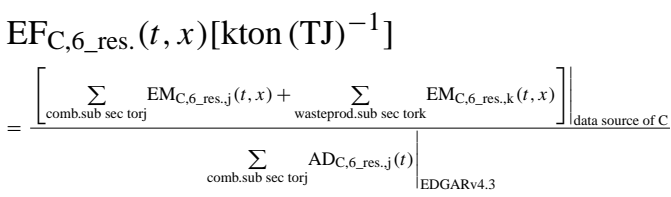

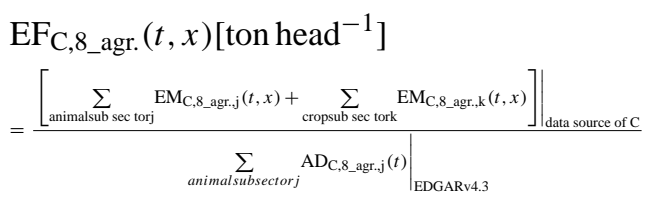

It should be noted that the implied emission factors of sectors htap_4_INDUSTRY and htap_8_AGRICULTURE are slightly skewed because of an incomplete accounting of the activity data, which are for these sectors a combination of activities of different nature and as such expressed with different units. The emissions of sector htap_4_INDUSTRY mainly originate from the energy-intensive subsectors and therefore are weighted with the energy needs (in TJ). We omitted the accounting of industrial process emissions, which are calculated per kton product manufactured. In sector htap_6_RESIDENTIAL the waste included, kton dry or wet waste, could not be combined with the residential energy consumption in TJ. The emissions of the htap_8_AGRICULTURE sector are weighted with the number of animals and not with the kton crops cultivated, because the crops serve for $85 \%$ as animal food and are therefore considered a justified measure of agricultural activity.

Thereto, emissions of sector-specific grid maps for 2010 have been aggregated to country level and divided with the activity data for that sector in that country from EDGARv4.3, 
(a)
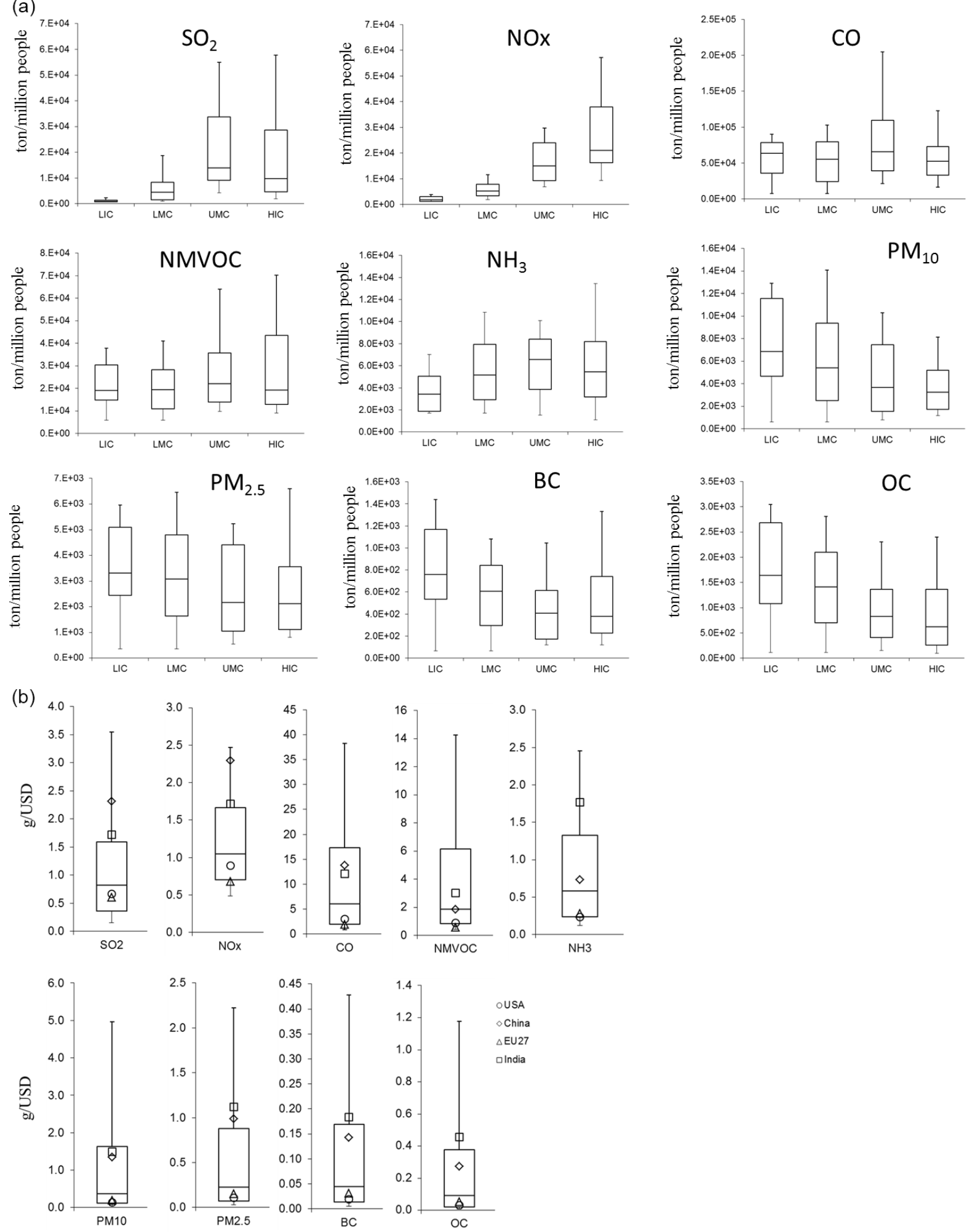

Figure 3. (a) 2010 per capita emissions per substance and per group of countries: low income (LIC), lower middle income (LMC), upper middle income (UMC) and high income (HIC) with the maximum, and minimum and the percentiles reported in the box plot (10, 50 and $\left.90^{\circ}\right)$ and the maximum and minimum in each group of countries. (b) Pollutant specific emissions divided by GDP ( $\mathrm{g} \mathrm{USD}^{-1}$ ) for the year 2010. Percentiles are reported in the box plots $\left(10,25,50,75\right.$ and $\left.90^{\circ}\right)$ together with emission/GDP for specific regions (EU27, USA, China and India). 
which are for energy-related activities based on IEA (2013) statistics and for agricultural-related activities on FAO (2012) statistics. It should be noted that emissions in particularly those reported under country-specific point sources are allocated to the reporting country solely, also for cells covering country borders. The areal fraction of these cells would incorrectly spread the emissions also the neighbouring country, which yield in the case of e.g. the power emissions for Canada up to $30 \%$ increase with the USA emissions along its borders. The implied emission factor results are given for all world countries and for 2010 in the Table S4 of Annex IV in the Supplement.

Figure 4 gives an overview per sector of the range of different implied emission factors for each country with the maximum/minimum, the percentiles and the median. In addition the position in this range of EU27, USA, China and India is indicated to evaluate the level of emission-intensity of the different activities. EU 27 and USA show very similar implied emission factors for the energy and industry sectors, which are much lower than the median for all pollutants. China also shows implied emission factors for energy and industry that are lower than the medians, but still larger than USA and EU 27. India shows much higher implied emission factors for energy and industry, which are for $\mathrm{CO}, \mathrm{PM}_{2.5}$, $\mathrm{BC}$, and $\mathrm{OC}$ above the median. In the case of the residential sector, the range of variation of the implied emission factors is the smallest for $\mathrm{SO}_{2}$ and $\mathrm{NO}_{x}$, but the largest for $\mathrm{PM}_{2.5}$ and $\mathrm{BC}$. For the transport sector a relatively large variation is present for $\mathrm{CO}$, with an implied emission factor for China that is above the median. For agriculture it is remarkable that China and India, as well as the USA and EU 27, have implied emission factors that are above the median, with China reaching the maximum compared to all other world countries.

Even though only implied emissions factors for country emissions are presented in Fig. 4, the implied emission factors were also calculated for the international bunker fuel and indicated that the implied emission factors are at the high end of the range for $\mathrm{SO}_{2}\left(0.98\right.$ ton $\mathrm{SO}_{2} \mathrm{TJ}^{-1}$ similar to the road transport emission factor of Laos or Panama), $\mathrm{NO}_{x}$ (with 1.65 ton $\mathrm{NO}_{x} \mathrm{TJ}^{-1}$ similar as for transport in Bangladesh or Myanmar), $\mathrm{PM}_{2.5}$ (with 0.17 ton $\mathrm{PM}_{2.5} \mathrm{TJ}^{-1}$ similar as for transport in China), but are relatively low for $\mathrm{CO}, \mathrm{NMVOC}$ and $\mathrm{BC}$. The high $\mathrm{SO}_{2}$ implied emission factor (from EDGARv4.3) represents the use of lower quality fuels in sea transportation, especially in international waters: $85 \%$ of the sea bunker fuel in 2010 consists of residual fuel oil with an emission factor of 1.29 ton $\mathrm{SO}_{2} \mathrm{TJ}^{-1}$.

\subsection{Emission changes 2008-2010}

The emission change from 2008 to 2010 is given in Table S2.3 of Annex II. It should be noted that the data provided for Canada by US-EPA/Environment Canada and for Europe by TNO were actually not representing 2010, but 2008 and 2009 , respectively. However, updates were undertaken: point source data of 2010 were used and implemented in the grid maps. Both regions were affected by the economic crisis of 2008, yielding stagnation and even downwards trends in the following years, mainly in the energy and industry sectors. The latter sectors are primarily composed of point sources; therefore the grid maps of 2010 represent also for Canada and Europe the actual 2010 situation. For the developed countries in North America and Europe, the decline of emissions between 2008 and 2010 for most of the pollutants are driven mostly by continued implementation of emission reduction technologies. In some cases this also leads to increases in sectorial emissions, although insignificant for the total, as is estimated for $\mathrm{NH}_{3}$ in the energy and transport sectors, due to the use of catalysts.

For the MICS-Asia region, the emissions are mostly increasing except for the energy sector, where the $\mathrm{SO}_{2}$ and PM emissions are reduced in 2010 due to the wide deployment of flue-gas desulfurization (FGD) and particulate matter filters in the power plants, consistent with Wang et al. (2014). For the other developing countries (calculated with the EDGARv4.3 data and based on the IEA (2013) fuel statistics), the $\mathrm{SO}_{2}$ emissions of the energy sector slightly increase from 2008 to 2010 because of the increased coal use (as also observed by Weng et al., 2012) and the increased use of heavy fuel oil in the Middle East. The PM emissions from the energy and industry of some other developing countries show a decrease from 2008 to 2010 , mainly due to the activity reduction and in some cases due to the modelled decrease in controlled emission factor in EDGARv4.3. Largest reductions were seen for Brazil (with 54\% reduction of its 2008 charcoal production) and Kazakhstan (11\% reduction in coal power generation, which is modelled with a $31 \%$ decreasing $\mathrm{BC}$ emission factor).

\subsection{Qualitative assessment of the uncertainty of emission grid maps}

Even though the HTAP_v2.2 data sources are all bottom-up constructed inventories, they differ considerably in e.g. the assumptions taken on the modelling of technology and endor-pipe measures and use different emission factors, which lead to inconsistencies at the borders between two adjacent inventories. On their turn the different bottom-up inventories are constructed with sub-regional (country, state, county or province level) activity data and emission factors. As such, inconsistencies can be expected at each country border, and the variation of the emissions at cross-border cells already gives us a first indication on the region- and sector-specific emission uncertainty. The propagation of uncertainty is given by the effect of variables' uncertainties (or errors) on the uncertainty; i.e. the variance of the activity data and that of the emission factor. Table 3 provides some insight in the estimation of the uncertainty range, however the approach followed in HTAP v2.2 inhibits an overall consistent uncertainty assessment because it is not one single bottom-up inventory. 

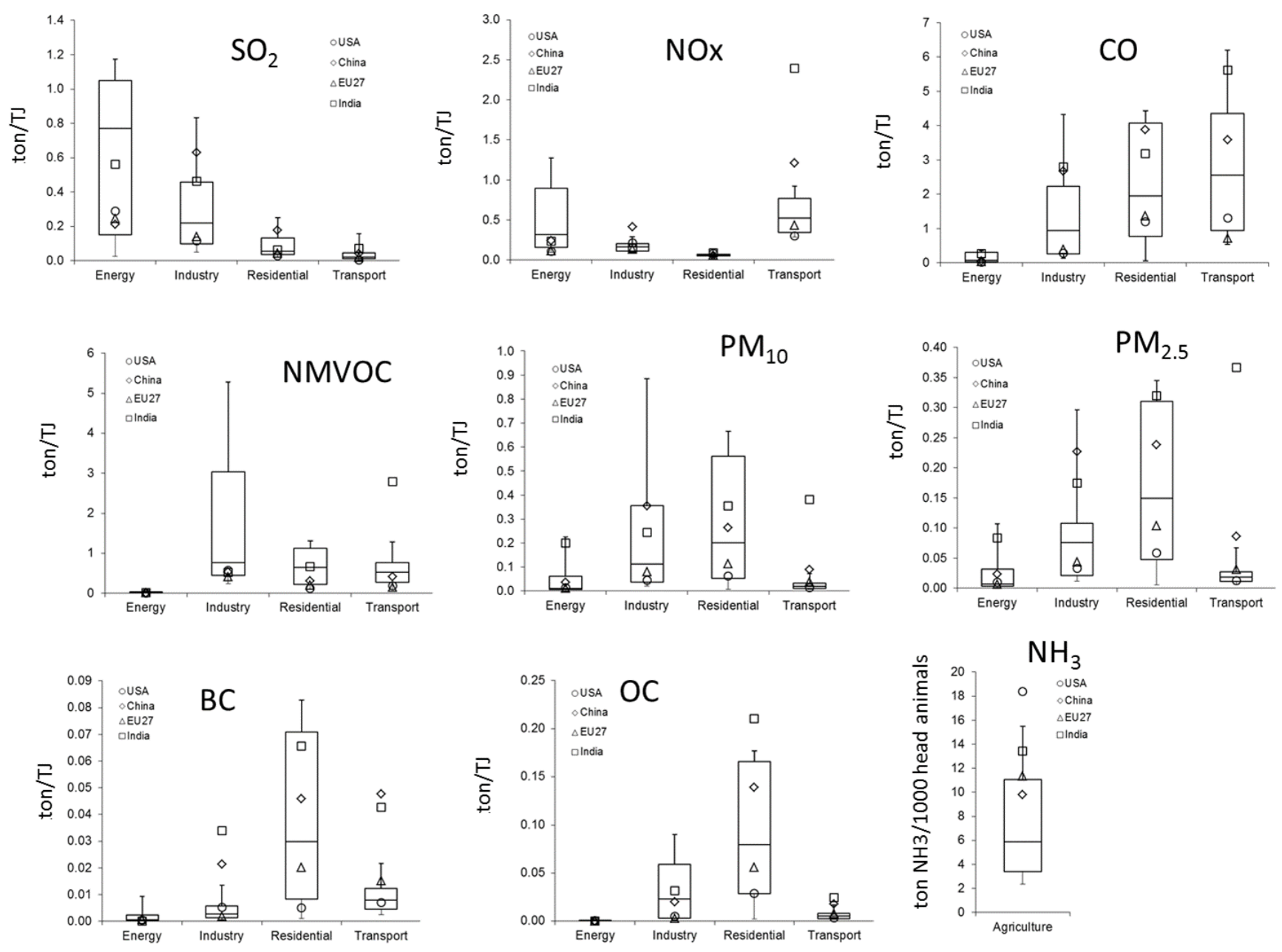

Figure 4. Sector specific implied emissions factors (ton $(\mathrm{TJ})^{-1}$ ) for the year 2010. Percentiles are reported in the box plots $(10,25,50$, 75 , and $90^{\circ}$ ) together with implied emission factors for specific regions (EU27, USA, China and India). Note - For the percentiles the following countries are left out. For CO - for the industry sector: Togo, Eritrea, Congo, Côte d'Ivoire, Kenya, Benin; for the residential sector: Maldives; for the transport sector: North Korea, Afghanistan, Laos, Tajikistan, Mongolia. For $\mathrm{SO}_{2}$ - for the industry sector: Namibia, Laos, Jamaica. For $\mathrm{NO}_{x}$ - for the residential sector: Maldives; for the TRANSPORT sector: Afghanistan, Laos, North Korea, Tajikistan. For NMVOC - for the energy sector: Bhutan; for the industry sector: Togo, Eritrea, Côte d'Ivoire, Congo, Cameroon, Kenya, Benin, Aruba, Antigua, Bahamas, Ethiopia, Sudan, Senegal, Equatorial Guinea, Central African Rep., Sri Lanka, Angola, Mozambique, Zambia, Jamaica; for the residential sector: American Samoa, Gum, Maldives, Tonga; for the transport sector: Afghanistan, Laos, North Korea. For PM $10-$

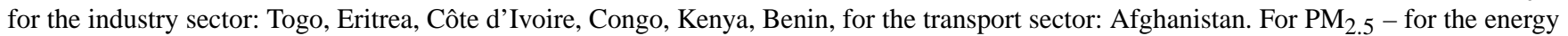
sector: Tajikistan, Luxembourg; for the industry sector: Togo and Eritrea; for the transport sector: Afghanistan. For BC - for the energy sector: Nigeria, Malaysia, Belgium, Oman, Finland, Georgia, Vietnam, Canada, Armenia, Tunisia, Jordan, The Netherlands, Trinidad and Tobago, Algeria, Latvia, United Arab Emirates, Brunei, Turkmenistan, Japan, Mozambique, Congo, Qatar, Bahrain, Moldova, Kyrgyzstan, South Korea, Taiwan, Luxembourg, Bhutan, Tajikistan; for the industry: Trinidad and Tobago, Malta; for the transport sector: Afghanistan. For OC - for the energy sector: Tunisia, Jordan, Trinidad and Tobago, Algeria, United Arab Emirates, Brunei, Turkmenistan, Tajikistan, Mozambique, Congo, Qatar, Bahrain, Kyrgyzstan, Taiwan, Myanmar, South Korea, Vietnam; for the industry sector: Bahrain, Eritrea; for the residential sector: Greenland, Gibraltar, Faroe Islands, Saint Pierre et Miquelon; for the transport sector: Afghanistan. For $\mathrm{NH}_{3}-$ for the agriculture sector: Faroe Islands, Tajikistan, Greenland, Falkland Islands, Kyrgyzstan, South Korea, Brunei, American Samoa, Malaysia, Trinidad and Tobago, Bahamas, Saint Pierre et Miquelon, Sri Lanka, Suriname, Réunion, Thailand, Indonesia, Japan, Barbados, Bhutan, Guyana, Costa Rica.

Guidance on evaluation of emission uncertainties can be obtained from the evaluations of the national inventories reported to UNFCCC, addressed by e.g. Jonas et al. (2010) (and references in there). With the evaluation of common behaviours between species in EDGARv4.2 of Balsama et al. (2014) we propose the same approach of $\mathrm{CO}_{2}$ uncertainty 
Table 3. Variables' uncertainties for sector- and country-specific totals per region with qualitative classification using the abbreviations low (L), low-medium (LM), upper-medium (UM), and high (H). The legend provides an interpretation of the level low, low-medium, uppermedium and high, which is indicatively specified for two groups of countries with two different statistical infrastructures.

\begin{tabular}{llllllllll}
\hline & $\mathrm{SO}_{2}$ & $\mathrm{NO}_{x}$ & $\mathrm{CO}$ & $\mathrm{NMVOC}$ & $\mathrm{NH}_{3}$ & $\mathrm{PM}$ & $\mathrm{BC} / \mathrm{OC}$ & With legend: \\
\hline htap1_AIR & $\mathrm{L}$ & $\mathrm{LM}$ & $\mathrm{LM}$ & $\mathrm{UM}$ & $\mathrm{LM}$ & $\mathrm{UM}$ & $\mathrm{UM}$ & $\begin{array}{l}\text { countries with well maintained } \\
\text { statistical infrastructure }\end{array}$ & $\begin{array}{l}\text { Countries with poorly maintained } \\
\text { statistical infrastructure }\end{array}$ \\
htap2_SHIPS & $\mathrm{L}$ & $\mathrm{LM}$ & $\mathrm{LM}$ & $\mathrm{UM}$ & $\mathrm{LM}$ & $\mathrm{H}$ & $\mathrm{H}$ & & \\
htap3_ENERGY & $\mathrm{L}$ & $\mathrm{LM}$ & $\mathrm{LM}$ & $\mathrm{UM}$ & $\mathrm{LM}$ & $\mathrm{UM}$ & $\mathrm{UM}$ & & $\mathrm{L}<35 \%$ \\
htap4_INDUSTRY & $\mathrm{LM}$ & $\mathrm{LM}$ & $\mathrm{LM}$ & $\mathrm{UM}$ & $\mathrm{UM}$ & $\mathrm{LM}$ & $\mathrm{LM}$ & $\mathrm{L}<15 \%$ & $35 \% \leq \mathrm{LM}<70 \%$ \\
htap5_TRANSPORT & $\mathrm{LM}$ & $\mathrm{UM}$ & $\mathrm{UM}$ & $\mathrm{UM}$ & $\mathrm{H}$ & $\mathrm{H}$ & $\mathrm{H}$ & $15 \% \leq \mathrm{LM}<50 \%$ & $70 \% \leq \mathrm{UM}<150 \%$ \\
htap6_RESIDENTIAL & $\mathrm{LM}$ & $\mathrm{UM}$ & $\mathrm{UM}$ & $\mathrm{UM}$ & $\mathrm{H}$ & $\mathrm{H}$ & $\mathrm{H}$ & $50 \% \leq \mathrm{UM}<100 \%$ & $150 \% \leq \mathrm{H}$ \\
htap8_AGRICULTURE & $\mathrm{UM}$ & $\mathrm{UM}$ & $\mathrm{UM}$ & $\mathrm{UM}$ & $\mathrm{H}$ & $\mathrm{H}$ & $\mathrm{H}$ & $100 \% \leq \mathrm{H}$ & \\
\hline
\end{tabular}

Note: The EMEP/EEA (2013) Guidebook's Uncertainties Chapter 5 for the absolute annual total of different pollutants have been taken into account to qualitatively indicate a low (L), low medium (LM), upper medium (UM) or high (H) uncertainty for the different sectors and species. Countries with well maintained infrastructure are mainly the 24 OECD (1990) countries and India. Other countries are considered to have a relative poorly maintained statistical infrastructure.

assessment for $\mathrm{SO}_{2}$ and $\mathrm{NO}_{x}$ (all driven by combustionrelated activities), and the approach of $\mathrm{N}_{2} \mathrm{O}$ for $\mathrm{NH}_{3}$. As such, Table 3 follows the grouping of countries by Andres et al. (2012) and Marland et al. (1999), based on their statistical infrastructure. Countries with well maintained statistical infrastructure are the 24 OECD-1990 countries plus India with a British statistical accounting system. For the other countries, a larger range in uncertainty is present, for which we refer to Gregg et al. (2008) or Tu (2011) and Olivier (2002). For the annual $\mathrm{CO}_{2}$ inventory, the biofuel is carbon-neutral and not taken up in the national inventories. However, for the air pollutants it is an additional large source of uncertainty, which is often not officially reported and as such missing. For the $\mathrm{N}$-related emissions, the division in countries could be based on common agricultural practices (Leip et al., 2011 and Rufino et al., 2014).

In addition to the uncertainty of the activities, the quality and representativeness of the controlled emission factors play a crucial role. The standard range of uncertainty already varies according to the EMEP/EEA (2013) Guidebook's Uncertainties Chapter 5 for the absolute annual total of different pollutants between at least $10 \%$ for $\mathrm{SO}_{2}$, at least $20 \%$ for $\mathrm{NO}_{x}$ and $\mathrm{CO}$, at least $50 \%$ for NMVOC, an order of magnitude for $\mathrm{NH}_{3}$, and $\mathrm{PM}_{10}, \mathrm{PM}_{2.5}, \mathrm{BC}$ and $\mathrm{OC}$. These considerations have been taken into account to indicate qualitatively a range for the different uncertainties (using the terminology low (L), low medium (LM), upper medium (UM) or high $(\mathrm{H}))$ for the different sectors and species.

The HTAP modelling community is expected to run in addition to the actual 2008 and 2010 simulations with the HTAP_v2.2 emission inventory also the emission scenarios of ECLIPSEv5 (Klimont et al., 2015). ECLIPSEv5 starts with a 2010 emission inventory (or base year inventory), that serves also as reference point for all projections. Here we compare the ECLIPSEv5 emission inventory for 2010 with the HTAP_v2.2 2010 data, in order to evaluate how close the reference point is to the "officially accepted" regional inventories of HTAP_v2.2. At the global level, a relatively good agreement is found with small relative emis- sion differences (ECLIPSEv5 - HTAPv2.2)/HTAPv2.2 for the aggregated sectors in 2010. It should be noted that the GAINS data set, another bottom inventory, can not be considered an external independent source of verification, because similar information on emission factors and reductions for certain technologies have been applied in the TNO-EMEP, MIX-Asia and EDGARv4.3 data sets. The relative difference for $\mathrm{NO}_{x}$ and $\mathrm{CO}$ is only $-4 \%$ and $+5 \%$, respectively. For $\mathrm{SO}_{2}$ a larger difference of $-8 \%$ reflects the recent important S-reductions for the non-ferrous metal smelters in ECLIPSEv5 (Klimont et al., 2013). For $\mathrm{NH}_{3}$ a relative difference of $+17 \%$ is acceptable because of the larger uncertainty in emission factors driven by lack of information about manure management practices and also by incomplete data on the agricultural activities. For NMVOC a difference of $-27 \%$ stems primarily from the assumptions about emissions from solvent use. The information about activity levels is scarce and even less is known about the emission factors for some important sources. Both regional inventory compilers and modellers often make assumptions about per capita or per GDP solvent use NMVOC emissions from particular sectors. Here assumptions employed in the ECLIPSEv5 lead to lower emissions from these activities. As anticipated (and reflected in Table 3) larger differences of 48 and $29 \%$ are present for $\mathrm{PM}_{2.5}$ and $\mathrm{BC}$, respectively. While for $\mathrm{PM}_{2.5}$, assumptions about penetration and efficiency of filters in industrial and small-scale residential boilers as well as emission factors and activity data for biomass used in cooking stoves play a key role, for BC assumptions about coal consumption in East Asia are of relevance since ECLIPSEv5 relied on provincial statistics for China which results in higher coal consumption than reported in national statistics and IEA. Additionally, ECLIPSEv5 includes emissions from kerosene wick lamps, especially relevant for South Asia and parts of Africa according to Lam et al. (2012), gas flaring and high emitting vehicles, which together result in about $30 \%$ higher emissions.

In addition, the spatial allocation is subject to other types of errors, with a spatial variance for point sources and a more important systematic error when a spatial proxy is used to 
distribute the emissions. Geo-spatial consistency is lower in the HTAP_v2.2 database than if the national totals would have been spatially redistributed with one harmonised spatial proxy data set. It should be also noted that derivation of country totals from the $0.1^{\circ} \times 0.1^{\circ}$ emission grid maps (as e.g. done in the ECCAD system) is only valid if the countryspecific total is larger than $0.2 \%$ of each of the totals of the neighbouring countries. Otherwise the derived countryspecific sector total can be $50 \%$ larger than the bottom-up one, mainly in the energy sector with many point sources which are typically located on waterways or coastal areas and as such in cross border cells. Table S1.3 illustrates the deviations of derived country-specific sector totals to the bottom-up ones for the Asian region. The latter caused derived sector totals for Kyrgyzstan, Tajikistan, Afghanistan, Laos, Myanmar, Bangladesh, which deviated with 1 order of magnitude from the bottom-up totals. However, the relatively small differences for China $(\leq 5 \%)$, India $(\leq 3 \%$ for all except for $\mathrm{SO}_{2}$ from energy where it is $\left.14 \%\right)$, Indonesia $(\leq 7 \%)$ and Thailand $(\leq 12.5 \%)$, Japan $(\leq 16.0 \%)$ and South Korea $(\leq 17.3 \%)$ show a good agreement for the top six Asian emitters.

Another type of inconsistency in mass balance at grid cell level occurs when for the same region the data sources providing the emission grid maps for $\mathrm{PM}_{10}$ and $\mathrm{PM}_{2.5}$ or for $\mathrm{PM}_{2.5}$ and $\mathrm{BC} / \mathrm{OC}$ are different. Already the application of different spatial proxy data sets (e.g. with and without point sources) result in an inconsistent allocation of multi-pollutant sources to different grid cells. This was another reason not to use the PM grid maps of EMEP, as no BC and OC speciation is available from the same EMEP data source. Instead we used the grid maps of TNO for all PM components $\left(\mathrm{PM}_{10}\right.$ and $\mathrm{PM}_{2.5}$ ) and the TNO speciation file for $\mathrm{BC}$ and OC. In addition a check was performed to ensure that the sum of $\mathrm{BC}$ and $\mathrm{OC}$ emissions in every grid cell is smaller than the $\mathrm{PM}_{2.5}$ emission in that grid cell. Thereto a re-allocation of the emissions of some point sources (industrial facilities) was needed within Europe (e.g. Poland) and performed in consultation with TNO.

Even though this mosaic inventory can not present the same consistency as one global bottom-up inventory, its extensive evaluation and use helped improving its quality. The evaluation was undertaken in particular in discussion with TNO and with US EPA to identify missing sources or misallocation of point sources. In particular point sources are very important input, but their strengths and locations are subject to input errors with larger consequences and cannot be extrapolated in time. (Closure of power plants as large point sources can change the emission distribution pattern from 1 year to another.) In addition the use of the data set by global and regional climate and air quality modellers and the modellers' feedback (L. Emmons, personal communications, 5 November 2013 and D. Henze, personal communication, 19 November 2013) were most useful and are further encouraged.

\section{Conclusions and recommendations}

This paper describes the HTAP global air pollutant reference emission inventory for 2010, which is composed of latest available data from regional inventory compilers. It assures a consistent input for both regional and global modelling as required by the HTAP modelling exercise. The HTAP_v2.2 emission database makes use of consolidated estimates of official and latest available regional information with air pollutant grid maps from US EPA and Environment Canada for North America, EMEP-TNO for Europe, MIX for Asia, and the EDGARv4.3 database for the rest of the world. The mosaic of grid maps provides comprehensive local information on the emission of air pollutants, because it results from the collection of point sources and national emission grid maps at $0.1^{\circ}$ (for some regions $0.25^{\circ}$ ) resolution. Even though the HTAP_v2.2 data set is not a self-consistent bottom-up database with activity data of consistent international statistics, with harmonized emission factors, and with global sets of spatial proxy data, it provides a unique set of emission grid maps with global coverage and high spatial resolution, including in particular important point sources. The compilation of implied emission factors and per capita emissions for the different world regions using multiple sources provides the regional and national emission inventory compilers with a valuable asset for comparison with their own data for cross checking and analysis which may lead to identification of future improvement options.

This data set was prepared as emission input for the HTAP community of modellers and its preparation has involved outreach to global and regional climate and air quality modellers (collaborating also within the AQMEII and MICSAsia modelling exercises). The TF HTAP needed an emission inventory that was suitable for simultaneous and comparable modelling of air quality at the regional scale and at the global scale to deliver consistent policy support at both scales. The HTAP-v2.2 emission inventory presented in this paper is tailor-made to allow the TF HTAP to fulfil its prime objectives and contribute to a common international understanding of global and regional air pollution and its influence on human health, vegetation and climate. The use of the HTAPv2.2 inventory will substantially help to provide a basis for future international policies because it combines and is consistent with the inventories that are used for regional (EU, US Canada, China) policy analysis and support.

\section{Data availability}

The $0.1^{\circ} \times 0.1^{\circ}$ emission grid maps can be downloaded from the EDGAR website on http://edgar.jrc.ec.europa.eu/ htap_v2/index.php?SECURE=_123 per year, per substance and per sector either in the format of netcdf-files or .txt files. The emissions in the netcdf-files are expressed in $\mathrm{kg}$ substance $\mathrm{m}^{-2} \mathrm{~s}^{-1}$ but the emissions in the .txt are in ton substance/gridcell. For the NMVOC speciated grid maps we 
refer to the link on the ECCAD data portal: http://eccad2. sedoo.fr/eccad2/mapdisplay.xhtml?faces-redirect=_true.

\section{The Supplement related to this article is available online at doi:10.5194/acp-15-11411-2015-supplement.}

Acknowledgements. This research was partially funded by EC-DG Environment under AA 070402/2007/47597/ MAR/C5 and 33075. S. Galmarini (JRC) and A. Zuber (DG Environment) are thanked for the continuing support to the HTAP project. The authors would also like to thank all HTAP-modelers providing first feedback. Colleagues of the ECCAD project, C. Granier, A. Mieville, of the TNO-MACC project and of EMEP-MSCW are gratefully acknowledged for help provided during the preparation of this work.

Edited by: G. Carmichael

\section{References}

Anderson, S. T., Parry, I. W. H., Sallee, J. M., and Fischer, C.: Automobile Fuel Economy Standards: Impacts, Efficiency, and Alternatives, Rev. Environ. Econom. Pol., 5, 89-108, doi:10.1093/reep/req021, 2011.

Andres, R. J., Boden, T. A., Bréon, F.-M., Ciais, P., Davis, S., Erickson, D., Gregg, J. S., Jacobson, A., Marland, G., Miller, J., Oda, T., Olivier, J. G. J., Raupach, M. R., Rayner, P., and Treanton, K.: A synthesis of carbon dioxide emissions from fossil-fuel combustion, Biogeosciences, 9, 1845-1871, doi:10.5194/bg-9-18452012, 2012.

Balsama, A., De Biase, L., Janssens-Maenhout, G., and Pagliari, V.: Near-term forecast of anthropogenic emission trends using neural networks, J. Atmos. Environ., 89, 581-592, doi:10.1016/j.atmosenv.2014.02.046, 2014.

Boitier, B.: $\mathrm{CO}_{2}$ emissions production-based accounting vs consumption: Insights from the WIOD databases, WIOD Final Conference - Causes and Consequences of Globalization, Groningen, 24-26 April, 2012.

Carmichael, G. R., Sakurai, T., Streets, D., Hozumi, Y., Ueda, H., Park, S. U., Funge, C., Han, Z., Kajino, M., Engardt, M., Bennet, C., Hayami, H., Sartelet, K., Holloway, T., Wang, Z., Kannari, A., Fu, J., and Matsuda, K.: Thongboonchoo, N., Amann, M.: MICS-Asia II: The model intercomparison study for Asia Phase II methodology and overview of findings, Atmos. Environ., 42, 3468-3490, doi:10.1016/j.atmosenv.2007.04.007, 2008.

Davis, S. J., Peters, G. P., and Caldeira, K.: The Supply Chain of $\mathrm{CO}_{2}$ Emissions, P. Natl. Acad. Sci. USA, 108, 18554-18559, doi:10.1073/pnas.1107409108, 2011.

EC-JRC/PBL: European Commission, Joint Research Centre (JRC)/Netherlands Environmental Assessment Agency (PBL): Emission Database for Global Atmospheric Research (EDGAR), release EDGAR version 4.2, http://edgar.jrc.ec.europa.eu/ (last access: December 2013), 2011.
EC-JRC/PBL: European Commission, Joint Research Centre (JRC)/Netherlands Environmental Assessment Agency (PBL): Emission Database for Global Atmospheric Research (EDGAR), release EDGAR version 4.3, http://edgar.jrc.ec.europa.eu/ (last access: October 2015), 2015.

EMEP: Draft Guidelines for Estimating and Reporting Emissions Data, prepared by the Task Force on Emission Inventories and Projections and the secretariat, [E/ECE/EB.AIR/GE.1/2002/7, Geneva: UN, 64 p., map, tables, issued under agenda items 5 and 5f of agenda [E/ECE]EB.AIR/GE.1/2002/1, 2 July, 2002.

EMEP/EEA: EMEP/EEA air pollutant emission inventory guidebook 2013: Technical guidance to prepare national emission inventories, ISSN 1725-2237, EEA Techn. Report 12/2013, http: //www.eea.europa.eu/publications/emep-eea-guidebook-2013 (last access: December 2014), 2013.

EPA, US: The 2008 National Emissions Inventory, 2008 NEI version 3, Techn. Support Documentation, http://www.epa.gov/ ttnchie1/net/2008inventory.html (last access: December 2014), 2013.

Eurostat, European Statistics Database of the European Commission, (datasets tsdpc260 and demo_pjan), http://ec.europa.eu/ eurostat/data/database (last access: July 2015), 2014.

FAO: Food and Agricultural Organization of the United Nations: Statistics Division, Livestock, Crop and Fertilizer data, faostat.fao.org, and Geonetwork Digital Soil Map of the World, http://www.fao.org/geonetwork/srv/en/metadata. show?id=14116\&currTab=simple (last access: December 2013), 2012.

Galmarini, S., Rao, S. T., and Steyn, D.: Preface: Special issue of Atmospheric Environment for AQMEII. Atm. Env. Elsevier Science Ltd, New York, NY, 53, 1-3, 2012.

Galmarini, S., Hogrefe, C., Brunner, D., Baklanov, A., and Makar, P.: Preface: Special issue of Atmospheric Environment for AQMEII phase 2, J. Atmos. Environ., 115, 340-344, 2015.

Gregg, J. S., Andres, R. J., and Marland, G.: China: Emissions pattern of the world leader in $\mathrm{CO}_{2}$ emissions from fossil fuel consumption and cement production, Geophys. Res. Lett., 35, L08806, doi:10.1029/2007g1032887, 2008.

HTAP, UNECE: Hemispheric Transport of Air Pollution 2010: Part A: Ozone and Particulate Matter, Air Pollution Studies No. 17, edited by: Dentener, F., Keating, T., and Akimoto, H., ECE/EN.Air/100, ISSN 1014-4625, ISBN 978-92-1-117043-6, 2010.

Huang, X., Song, Y., Li, M., Li, J., Huo, Q., Cai, X., Zhu, T., Hu, M., and Zhang, H.: A high-resolution ammonia emission inventory in China, Global Biogeochem. Cy., 26, GB1030, doi:10.1029/2011GB004161, 2012.

IEA: Energy Statistics of OECD and Non-OECD Countries, data. iea.org(last access: December 2013), (IEA/EXD/ECD3), 2013.

IMF: World Economic Outlook Database, International Monetary Fund, http://www.imf.org/external/pubs/ft/weo/2014/02/ weodata/index.aspx(last add last access: October 2014), 2014.

IMO: Second IMO Greenhouse Gas Study 2009, http://www.ce.nl/ publicatie/second_imo_ghg_study_2009/941 (last access: July 2015), 2009.

IMO: Reduction of GHG Emissions from Ships - Third IMO GHG Study 2014, http://www.imo.org/en/OurWork/ Environment/PollutionPrevention/AirPollution/Pages/ 
Greenhouse-Gas-Studies-2014.aspx (last access: July 2015), 2014.

IPCC: 2006 IPCC Guidelines for National Greenhouse Gas Inventories, IPCC National Greenhouse Gas Inventory Programme, available at: http://www.ipcc-nggip.iges.or.jp/public/ 2006gl/index.html (last access: December 2013), Hayama, Japan, 2006.

IPCC: Climate Change 2014: Mitigation of Climate Change. Contribution of Working Group III to the Fifth Assessment Report of the Intergovernmental Panel on Climate Change, edited by: Edenhofer, O., Pichs-Madruga, R., Sokona, Y., Farahani, E., Kadner, S., Seyboth, K., Adler, A., Baum, I., Brunner, S., Eickemeier, P., Kriemann, P., Savolainen, J., Schlömer, S., von Stechow, C., Zwickel, T., and Minx J. C., Cambridge University Press, Cambridge, UK and New York, NY, USA, 2014.

Janssens-Maenhout, G., Dentener, F., van Aardenne, J., Monni, S., Pagliari, V., Orlandini, L., Klimont, Z., Kurokawa, J., Akimoto, H., Ohara, T., Wankmüller, R., Battye, B., Grano, D., Zuber, A., and Keating, T.: EDGAR-HTAP: a harmonized gridded air pollution emission dataset based on national inventories, EUR 25229 EN Report, ISBN 978-92-79-23122-3, ISSN 1018-5593, doi:10.2788/14069, 2012.

Janssens-Maenhout, G., Pagliari, V., Guizzardi, D., and Muntean, M.: Global emission inventories in the Emission Database for Global Atmospheric Research (EDGAR) - Manual (I): Gridding: EDGAR emissions distribution on global gridmaps, JRC Report, EUR 25785 EN, ISBN 978-92-79-28283-6, doi:10.2788/81454, 2013.

Jonas, M., Marland, G., Winiwarter, W., White, T., Nahorski, Z., Bun, R., and Nilsson, S.: Benefits of dealing with uncertainty in greenhouse gas inventories: introduction, Climatic Change, 103, 3-18, doi:10.1007/s10584-010-9922-6, 2010.

JPEC (Japan Petroleum Energy Center): Emission inventory of road transport in Japan, JPEC Technical Report, Japan Petroleum Energy Center, Tokyo, Japan, JPEC-2011AQ-02-06, 136 pp., 2012a (in Japanese).

JPEC: Emission inventory of sources other than road transport in Japan, Japan Petroleum Energy Center, Tokyo, Japan, JPEC Technical Report, JPEC-2011AQ-02-07, 288 pp., 2012b (in Japanese).

JPEC: Speciation profiles of VOC, PM, and $\mathrm{NO}_{x}$ emissions for atmospheric simulations of $\mathrm{PM}_{2.5}$, Japan Petroleum Energy Center, Tokyo, Japan, JPEC Technical Report, JPEC-2011AQ-02-08, 69 pp., 2012c (in Japanese).

Klimont, Z., Smith, S., and Cofala, J.: The last decade of global anthropogenic sulfur dioxide: 2000-2011 emissions, Environ. Res. Lett., 8, 014003, doi:10.1088/1748-9326/8/1/014003/, 2013.

Klimont, Z., Hoeglund-Isaksson, L., Heyes, C., Rafaj, P., Schoepp, W., Cofala, J., Borken-Kleefeld, J., Purohit, P., Kupiainen, K., Winiwarter, W., Amann, M., Zhao, B., Wang, S., Bertok, I., and Sander, R.: Global scenarios of air pollutants and methane: 1990-2050, Atmos. Chem. Phys., in preparation, 2015.

Kuenen, J. J. P., Visschedijk, A. J. H., Jozwicka, M., and Denier van der Gon, H. A. C.: TNO-MACC_II emission inventory: a multiyear (2003-2009) consistent high-resolution European emission inventory for air quality modelling, Atmos. Chem. Phys. Discuss., 14, 5837-5869, doi:10.5194/acpd-14-5837-2014, 2014.

Kurokawa, J., Ohara, T., Morikawa, T., Hanayama, S., Greet, J.M., Fukui, T., Kawashima, K., and Akimoto, H.: Emissions of air pollutants and greenhouse gases over Asian regions during 2000-2008: Regional Emission inventory in ASia (REAS) version 2, Atmos. Chem. Phys. Discuss., 13, 10049-10123, doi:10.5194/acpd-13-10049-2013, 2013.

Lam, N. L., Chen, Y., Weyant, C., Venkataraman, C., Sadavarte, P., Johnson, M. A., Smith, K. R., Brem, B. T., Arineitwe, J., Ellis, J. E., and Bond, T. C.: Household Light Makes Global Heat: High Black Carbon Emissions From Kerosene Wick Lamps, Environ. Sci. Technol., 46, 13531-13538. doi:10.1021/es302697h, 2012.

Lamarque, J.-F., Bond, T. C., Eyring, V., Granier, C., Heil, A., Klimont, Z., Lee, D., Liousse, C., Mieville, A., Owen, B., Schultz, M. G., Shindell, D., Smith, S. J., Stehfest, E., Van Aardenne, J., Cooper, O. R., Kainuma, M., Mahowald, N., McConnell, J. R., Naik, V., Riahi, K., and van Vuuren, D. P.: Historical (1850-2000) gridded anthropogenic and biomass burning emissions of reactive gases and aerosols: methodology and application, Atmos. Chem. Phys., 10, 7017-7039, doi:10.5194/acp10-7017-2010, 2010.

Lee, D. G., Lee, Y.-M., Jang, K.-W., Yoo, C., Kang, K.-H., Lee, J.-H., Jung, S.-W., Park, J.-M., Lee, S.-B., Han, J.-S., Hong, J.H., and Lee, S.-J.: Korean national emissions inventory system and 2007 air pollutant emissions, Asian, J. Atmos. Environ., 5, 278-291, 2011.

Leip, A., Achermann, B., Billen, G., Bleeker, A., Bouwman, A.F., de Vries, W., Dragosits, U., Döring, U., Fernall, D., Geupel, M., Herolstab, J., Johnes, P., Le Gall, A.C., Monni, S., Nevečeřal, R., Orlandini, L., Prud'homme, M., Reuter, H.I., Simpson, D., Seufert, G., Spranger, T., Sutton, M. A., van Aardenne, J., Voß, M., and Winiwarter, W.: Integrating nitrogen fluxes at the European scale, Chapter 16 in The European Nitrogen Assessment edited by: Sutton, M. A., Howard, C. M., Erisman, J. W., Billen, G., Bleeker, A., Grennfelt, P., van Grinsven, H., and Grizzetti, B., Cambridge University Press, Cambridge, 2011.

Li, M., Zhang, Q., Kurokawa, J., Woo, J.-H., He, K. B., Lu, Z., Ohara, T., Song, Y., Streets, D. G., Carmichael, G. R., Cheng, Y. F., Huo, H., Liu, F. Su, H., and Zheng, B.: MIX: a mosaic Asian anthropogenic emission inventory for the MICS-Asia and the HTAP projects, Atmos. Phys. Chem, in preparation, 2015.

Lu, Z., Zhang, Q., and Streets, D. G.: Sulfur dioxide and primary carbonaceous aerosol emissions in China and India, 1996-2010, Atmos. Chem. Phys., 11, 9839-9864, doi:10.5194/acp-11-98392011, 2011.

Mareckova, K., Wankmueller, R., Moosmann, L., and Pinterits, M.: Inventory Review 2013: Review of emission data reported under the LRTAP Convention and NEC Directive: Stage 1 and 2 review, Status of gridded and LPS data, EMEP/EEA, Technical Report CEIP 1/2013, 2013.

Marland, G., Brenkert, A., and Olivier, J.: $\mathrm{CO}_{2}$ from fossil fuel burning: a comparison of ORNL and EDGAR estimates of national emissions, Environ. Sci. Policy, 2, 265-273, doi:10.1016/S1462-9011(99)00018-0, 1999.

Mejía-Centeno, I., Martínez-Hernández, A., and Fuentes, G. A.: On The Enhanced Emission Of $\mathrm{NH}_{3}$ And Fine Particles From Gasoline Vehicles Operating With Low Sulfur Gasoline, Topics Catal, 2007, AIChe, Ann. M., 2007.

MOEJ (Ministry of Environment of Japan): Report on Volatile Organic Compound (VOC) Emission Inventory Compiled, available at: http://www.env.go.jp/air/osen/voc/inventory.html (last access: December 2012), 2009 (in Japanese). 
Moss, R. H., Edmonds, J. A., Hibbard, K. A., Manning, M. R., Rose, S. K., van Vuuren, D. P., Carter, T. R., Emori, S., Kainuma, M., Kram, T., Meehl, G. A., Mitchell, J. F. B., Nakicenovic, N., Riahi, K., Smith, S., Stouffer, R. J., Thomson, A. M., Weyant, J. P., and Wilbanks, T. J.: The next generation of scenarios for climate change research and assessment, Nature, 463, 747-756, 2010.

Olivier, J. G. J.: On the Quality of Global Emission Inventories: Approaches, Methodologies, Input Data and Uncertainties, $\mathrm{PhD}$ thesis, University Utrecht, Utrecht, ISBN 90-393-3103-0, 2002.

Olivier, J. G. J. and Janssens-Maenhout, G.: $\mathrm{CO}_{2}$ Emissions from Fuel Combustion - 2012 Edition, IEA $\mathrm{CO}_{2}$ report 2012, Part III, Greenhouse-Gas Emissions, ISBN 978-92-64-17475-7, 2012.

Olivier J. G. J., Janssens-Maenhout, G., and Peters, J. A. H. W.: Trends in global $\mathrm{CO}_{2}$ emissions, 2013 report, JRC tech. note RC83593, ISBN 978-9491506-51-2, http://edgar.jrc.ec.europa.eu/news_docs/ pbl-2013-trends-in-global-co2-emissions-2013-report-1148. pdf, EUR 26098 EN 2013, 2013.

OPRF (Ocean Policy Research Foundation (Ship and Ocean Foundation)): Report for comprehensive study for environmental impact lead by the establishment of emission control area in Japan, OPRF report, Minato-ku, Tokyo, Japan, ISBN 978-4-88404-2820, 524 pp., 2012 (in Japanese).

Pouliot, G., Keating, T., Janssens-Maenhout, G., Chang, C., Beidler, J., and Cleary, R.: The Incorporation of the US National Emission Inventory into Version 2 of the Hemispheric Transport of Air Pollutants Inventory, in Air Pollution Modeling and its Application XXIII, edited by: Steyn, D. and Mathur, R., 265-268, Springer International Publishing, USA, 2014.

Pouliot, G., Denier van der Gon, H. A. D., Kuenen, J., Zhang, J., Moran, M. D., and Makar, P. A.: Analysis of the emission inventories and model-ready emission datasets of Europe and North America for phase 2 of the AQMEII project, J. Atmos. Environ., 115, 345-360, doi:10.1016/j.atmosenv.2014.10.061, 2015.

Ramanathan, V. and Feng, Y.: Air pollution, greenhouse gases and climate change: Global and regional perspectives, Atmos. Environ., 43, 37-20, 2009.

Rufino, M. C., Brandt, P., Herrero, M., and Butterback-Bahl, K.: Reducing uncertainty in nitrogen budgets for African livestock systems, Environ. Res. Lett., 9, 105008, doi:10.1088/17489326/9/10/105008, 2014.

Streets, D., van Aardenne, J., Battye, B., Garivait, S., Grano, D., Guenther, A., Klimont, Z., Lamarque, J.-F., Lu, Z., JanssensMaenhout, G., Ohara, T., Parrish, D., Smith, S., and Vallack, H.: HTAP Report, Part A: Chapter 3: Emission Inventories and Projections, in: Air pollution studies No. 17 of the UNECE, Hemispheric Transport of Air Pollution 2010, Part A: Ozone and Particulate Matter, edited by: Dentener, F., Keating, T, and Akimoto, H., ISBN 978-92-1-117043-62010.
Tu, K. J.: Industrial organisation of the Chinese coal industry. Freeman Spogli Institute for International Studies, Working Paper 103, http://carnegieendowment.org/files/China_Coal_Value_ Chain_Kevin_Tu3.pdf (last access: July 2015), 2011.

UNFCCC: NIR submissions of the greenhouse gas inventories for Annex I countries, http://unfccc.int/national_reports/annex_i_ ghg_inventories/national_inventories_submissions/items/7383. php (last access: July 2015), 2013.

UNPD (UN Population Division): World Population Prospects (WPP), The 2012 Revision, UN Department of Economic and Social Affairs, Population Division, 2013.

UNDP (UN Population Division): World Population Prospects (WPP), The 2015 Revision, UN Department of Economic and Social Affairs, Population Division, 2015.

van der Werf, G. R., Randerson, J. T., Giglio, L., Collatz, G. J., Mu, M., Kasibhatla, P. S., Morton, D. C., DeFries, R. S., Jin, Y., and van Leeuwen, T. T.: Global fire emissions and the contribution of deforestation, savanna, forest, agricultural, and peat fires (19972009), Atmos. Chem. Phys., 10, 11707-11735, doi:10.5194/acp10-11707-2010, 2010.

van Vuuren, D. P., Edmonds, J., Kainuma, M., Riahi, K., Thomson, A., Hibbard, K., Hurtt, G. C., Kram, T., Krey, V., Lamarque, J.-F., Matsui, T., Meinshausen, M., Nakicenovic, N., Smith, S. J., and Rose, S. K.: The representative concentration pathways: an overview, Climatic Change, , 109, 5-31, doi:10.1007/s10584011-0148-z, 2011.

Visschedijk, A. J. H., Denier van der Gon, H. A. C., and Droege, R.: A European high resolution and size-differentiated emission inventory for elemental and organic carbon for the year 2005, TNO report TNO-034-UT-3009-00688_RPT-ML, TNO, Utrecht, the Netherlands, 2009.

Wang, S. X., Zhao, B., Cai, S. Y., Klimont, Z., Nielsen, C. P., Morikawa, T., Woo, J. H., Kim, Y., Fu, X., Xu, J. Y., Hao, J. M., and He, K. B.: Emission trends and mitigation options for air pollutants in East Asia, Atmos. Chem. Phys., 14, 6571-6603, doi:10.5194/acp-14-6571-2014, 2014.

Weng, Z., Mudd, G. M., Martin, T., and Boyle, C. A.: Pollutant loads from coal mining in Australia: Discerning trends from the National Pollutant Inventory (NPI), Environ. Sci. Pollut., 19-20, 78, doi:10.1016/j.envsci.2012.03.003, 2012.

World Bank: Data from database: World Development Indicators, http://databank.worldbank.org/data/views/variableselection/ selectvariables.aspx? ?source=world-development-indicators\# (last access: July 2015), 2014.

Yevich, R. and Logan, J. A.: An assessment of biofuel use and burning of agricultural waste in the developing world, Global Biogeochem. Cy., 17, 1095, doi:10.1029/2002GB001952, 2003. 